\title{
www.freshwaterfungi.org, an online platform for the taxonomic classification of freshwater fungi
}

\author{
Calabon MS ${ }^{1,2,3}$, Hyde $\mathrm{KD}^{1,2,3}$, Jones $\mathrm{EBG}^{3,5,6}$, Chandrasiri $\mathrm{S}^{1,2,3}$, Dong $\mathrm{W}^{1,3,4}$, \\ Fryar $\mathrm{SC}^{7}$, Yang $\mathrm{J}^{1,2,3}$, Luo $\mathrm{ZL}^{8}$, Lu YZ $\mathrm{YZ}^{9}$, Bao $\mathrm{DF}^{1,4}$ and Boonmee $\mathrm{S}^{1,2^{*}}$ \\ ${ }^{1}$ Center of Excellence in Fungal Research, Mae Fah Luang University, Chiang Rai 57100, Thailand \\ ${ }^{2}$ School of Science, Mae Fah Luang University, Chiang Rai 57100, Thailand \\ ${ }^{3}$ Mushroom Research Foundation, 128 M.3 Ban Pa Deng T. Pa Pae, A. Mae Taeng, Chiang Mai 50150, Thailand \\ ${ }^{4}$ Department of Entomology and Plant Pathology, Faculty of Agriculture, Chiang Mai University, Chiang Mai 50200, \\ Thailand \\ ${ }^{5}$ Department of Botany and Microbiology, College of Science, King Saud University, P.O Box 2455, Riyadh 11451, \\ Kingdom of Saudi Arabia \\ ${ }^{6} 33 B$ St Edwards Road, Southsea, Hants., PO53DH, UK \\ ${ }^{7}$ College of Science and Engineering, Flinders University, GPO Box 2100, Adelaide SA 5001, Australia \\ ${ }^{8}$ College of Agriculture and Biological Sciences, Dali University, Dali 671003, People's Republic of China \\ ${ }^{9}$ School of Pharmaceutical Engineering, Guizhou Institute of Technology, Guiyang, 550003, Guizhou, People's \\ Republic of China
}

Calabon MS, Hyde KD, Jones EBG, Chandrasiri S, Dong W, Fryar SC, Yang J, Luo ZL, Lu YZ, Bao DF, Boonmee S. 2020 - www.freshwaterfungi.org, an online platform for the taxonomic classification of freshwater fungi. Asian Journal of Mycology 3(1), 419-445, Doi 10.5943/ajom/3/1/14

\begin{abstract}
The number of extant freshwater fungi is rapidly increasing, and the published information of taxonomic data are scattered among different online journal archives. The only online repository, http://fungi.life.illinois.edu/, deals with freshwater ascomycetes and their asexual morphs. Other freshwater fungal groups are not included. The newly developed webpage (www.freshwaterfungi.org/) serves as a gateway to freshwater fungal systematics that provides comprehensive and updated information including detailed descriptions, photographic plates and illustrations, notes, phylogenetic trees, estimated and extant list of species, and other related information. The website is developed with user-friendly interfaces, and the usage is discussed in this paper.
\end{abstract}

Key words - Database Website - Freshwater Ascomycota - Freshwater Basidiomycota Freshwater Chytridiomycota - Microsporidia - Molecular Phylogeny

\section{Introduction}

Freshwater fungi are an ecologically important group of fungi occurring in freshwater bodies throughout the world (Tsui \& Hyde 2003, Jones et al. 2014a). There have been various definitions of freshwater fungi, but most deal with ecological groups (Table 1). In this study, we prefer to use the definition of freshwater fungi as any species which, for the whole or part of their life cycle, rely on free freshwater, or which uses any resource of a predominantly aquatic or semi-aquatic nature as a substratum (Thomas 1996). This means that all fungi found in studies on submerged organic material, freshwater, sediments, foam and animals can be considered as freshwater fungi and are 
documented. Freshwater fungi occur in lentic (ponds, pools, lakes, peat swamps) and lotic (creeks, streams, brooks, rivers) habitats (Tsui \& Hyde 2003, Jones et al. 2014a). Floodplains and riparian zones are important intermediate habitats for survival and reproduction of freshwater fungi (Bärlocher 1992). Freshwater fungi also occur in artificial reservoirs such as water-cooling towers, water pipes, street gutters, wastewater treatment and sewage systems (Jones \& Eaton 1969, Eaton \& Jones 1970, 1971a, b, Udaiyan \& Hosagoudar 1991, Kane et al. 2002, Ghate \& Sridhar 2018, Grossart et al. 2019), and freshwater habitats with extreme conditions such as glacial waters (Buzzini et al. 2005, 2012, Vishniac 2006, de Garcia et al. 2007, Branda et al. 2010), ultraoligotrophic mountain lakes exposed to increased UV radiation (Libkind et al. 2004, Libkind et al 2014), hyper-acidic aquatic environments (Nakatsu \& Hutchinson 1988, López-Archilla et al. 2001, Gadanho \& Sampaio 2006, Gadanho et al. 2006) and sulfur thermal springs (Chandrashekar et al. 1991, Rajashekhar \& Kaveriappa 1996). The saprobic taxa are involved in the degradation of lignocellulose in woody material and cellulose in leaves (Eaton \& Jones 1971a, b, Jones 1972, 1981, Ballie et al. 1998, Yuen et al. 1999, Sridhar et al. 2010, Sridhar \& Sudheep 2011a, b, Sudheep \& Sridhar 2011, Bärlocher \& Sridhar 2014, Boonyuen et al. 2014). They are key players in the decomposition and mineralization of organic matters (Wong et al. 1998, Shearer et al. 2007, Jones et al. 2014a, Ittner et al. 2018, Raja et al. 2018). Some are parasites of aquatic plants and animals, while others are endophytes and mutualists (Srivastava \& Srivastava 1978, Wong et al. 1998, Sati \& Belwal 2005, Jobard et al. 2010, Ibelings et al. 2011, Gleason et al. 2014, 2015, Glockling et al. 2014, You et al. 2015, Ghate \& Sridhar 2017).

Freshwater fungi divide into various morphological and ecological groups (Shearer et al. 2007, Goh \& Hyde 1996). They include freshwater ascomycetes, freshwater hyphomycetes (Ingoldian fungi, aero-aquatic hyphomycetes or asexual ascomycetes, terrestrial-aquatic hyphomycetes, submerged-aquatic hyphomycetes), freshwater basidiomycetes, coelomycetes, zygomycetes, microsporidia and zoosporic fungi (Goh \& Hyde 1996, Tsui et al. 2016). The estimated number of freshwater fungi and fungal-like organisms are around 3,069-4,145, but these are underestimates as some groups are not listed or do not have enough available data. In addition, many habitats and substrates are unexplored or underexplored (Jones et al. 2014a). Freshwater fungi belong to eight phyla: Aphelidiomycota, Ascomycota, Basidiomycota, Blastocladiomycota, Chytridiomycota, Monoblepharomycota, Mortierellomycota and Rozellomycota with Ascomycota being the most speciose phylum (33 orders; 622 species and excluding ascomycetous yeasts) (Hibbett et al. 2007, Zhang et al. 2012, Jones et al. 2014a, Wijayawardene et al. 2018a, Wijayawardene et al. 2020).

Several books such as Recent Advances in Aquatic Mycology by Jones et al. (1976); Freshwater Mycology by Tsui \& Hyde (2003); Genera of Freshwater Fungi by Cai et al. (2006a); Freshwater Fungi: and fungal-like Organisms by Jones et al. (2014a), reviews (Shearer 1993, Goh \& Hyde 1996, Hyde et al. 1997, Wong et al. 1998, Gessner \& Van Ryckegem 2002, Shearer et al. 2007, Sridhar 2009, Wurzbacher et al. 2010, 2012, 2016, Chauvet et al. 2016), and monographs (Luo et al. 2019, Dong et al. 2020) of freshwater mycology have been published. The classifications have been significantly improved with the utilization of molecular data. The traditional classification of freshwater fungi was mainly based on morphological characters, such as fruit bodies and spores. However, classification has rapidly changed with the use of molecular data (Bärlocher 2010, Shearer et al. 2014, Duarte et al. 2015, Luo et al. 2019, Dong et al. 2020, Hyde et al. 2020b, Hongsanan et al. 2020). Phylogenetic analysis of extant species and the introduction of novel taxa has resulted in a modern classification system for the Kingdom Fungi (Hyde et al. 2013, Maharachchikumbura et al. 2016, Choi \& Kim 2017, Tedersoo et al. 2018, Luo et al. 2019, Naranjo-Ortiz \& Gabaldón 2019, Samarakoon et al. 2019, Hongsanan et al. 2020, Hyde et al. 2020b). Several new genera, families, orders, and even new subclasses of freshwater fungi have been introduced recently (Réblová et al. 2015a, b, 2016a, b, Maharachchikumbura et al. 2015, 2016, Su et al. 2016, Hongsanan et al. 2017, Wijayawardene et al. 2017, 2018a, Yang et al. 2017, 2018a, b, Zhang et al. 2017, Lu et al. 2018a, b, Bao et al. 2019a, b, Luo et al. 2019, Calabon et al. 2020a, b, c, Dong et al. 2020). Luo et al (2019) have provided a phylogenetic analysis for 
freshwater Sordariomycetes, while the Dothideomycetes are dealt with by Shearer et al. (2014) and Dong et al. (2020). Research on freshwater fungi has not been limited to taxonomy and identification. Researchers have also expanded knowledge through applied technology, and the future of freshwater fungal research and importance will grow (Sati \& Arya 2010, HernándezCarlos \& Gamboa-Angulo 2011, Krauss et al. 2011, Paguigan et al. 2016, Sati \& Pant 2018).

Table 1 Various definitions of freshwater fungi

\begin{tabular}{lll}
\hline \multicolumn{1}{c}{ Term } & \multicolumn{1}{c}{ Definition } & \multicolumn{1}{c}{ Reference } \\
\hline $\begin{array}{l}\text { Obligate freshwater } \\
\text { ascomycetes/Indwellers }\end{array}$ & $\begin{array}{l}\text { Fully adapted in water and often adapted for } \\
\text { dispersal in water }\end{array}$ & Park (1972) \\
\hline $\begin{array}{l}\text { Facultative freshwater } \\
\text { ascomycetes/Immigrants }\end{array}$ & $\begin{array}{l}\text { Originated from other habitats and must } \\
\text { continually immigrate to maintain their population } \\
\text { number in water; may show varying degrees of } \\
\text { adaptation }\end{array}$ & Park (1972) \\
\hline "Amphibious" freshwater & $\begin{array}{l}\text { Found in the interface between land and water } \\
\text { (e.g. riparian zones, floodplains); may be adapted } \\
\text { ascomycetes }\end{array}$ & $\begin{array}{l}\text { Michaelides \& Kendrick } \\
\text { (1978), Shearer (1993) }\end{array}$ \\
\hline Aeroaquatic hyphomycetes & $\begin{array}{l}\text { Indwelling organisms characterized by the } \\
\text { production of purely vegetative mycelium in } \\
\text { substrates underwater and formation of conidia } \\
\text { with special flotation devices, formed only when } \\
\text { the substrates on which the fungus is growing are } \\
\text { exposed to a moist environment }\end{array}$ & Fisher (1977) \\
\hline Freshwater ascomycetes & $\begin{array}{l}\text { All ascomycetes that occur on submerged or } \\
\text { partially submerged substrata in aquatic habitats }\end{array}$ & Shearer (1993) \\
\hline Freshwater fungi & $\begin{array}{l}\text { Fungi that for the whole or part of their life cycle } \\
\text { rely on freshwater, or which uses any resource of a } \\
\text { predominantly aquatic or semi-aquatic nature as a } \\
\text { substratum }\end{array}$ & Thomas (1996) \\
\hline Those isolated from freshwater or foam & Jones \& Slooff (1966) \\
\hline Fquatic hyphomycetes & $\begin{array}{l}\text { Hyphomycetes that able to sporulate under water } \\
\text { and thrive on deciduous leaves decaying in streams } \\
\text { and rivers. }\end{array}$ & Krauss et al. (2011) \\
\hline
\end{tabular}

Online databases serve as data repositories to amass all information in one platform (Shearer \& Raja 2010, Jayasiri et al. 2015, Jayawardena et al. 2019, Jones et al. 2019, Monkai et al. 2019, Pem et al. 2019, Bundhun et al. 2020). Currently, the webpage http://fungi.life.illinois.edu/ deals with freshwater fungi, but it includes only the freshwater ascomycetes and their asexual morphs. To document all freshwater fungi at all taxonomic levels, the website www.freshwaterfungi.org is developed to provide up-to-date information for all taxa. The present paper introduces the website and discusses its features and functions.

\section{History of freshwater fungi}

Freshwater fungi, especially the freshwater hyphomycetes, have been observed as early as the 1880s. The tetraradiate, sigmoid and branched conidia were an interesting character that caught the attention of pioneer mycologists. Heliscus lugdunensis was the first described freshwater hyphomycete species (Saccardo 1880), while Flagellospora penicillioides was the first aquatic hyphomycete where the sexual state was known (Ranzoni 1956). An important contribution to aquatic hyphomycete research is that of de Wildeman $(1893,1894,1895)$ who described four new fungal species, three with tetraradiate and one with sigmoid conidia, from ponds, ditches and marshy areas on different substrates (algae, willow leaves, aquatic macrophytes Hippuris vulgaris). The first prolific sporulation of freshwater hyphomycete in vitro was by Kegel (1906) for Varicosporium elodeae, wherein the induction of sporulation occurs when overgrown agar blocks were placed in nutrient-poor water. Some authors who worked on freshwater were Grove (1912), 
Fragoso (1920), Huber-Pestalozzi (1925, 1938), Brutschy (1927) and Lowe (1927). A major breakthrough occurred when Ingold (1942) discovered a typical habitat for freshwater fungi, growing on submerged decaying leaves of broad-leaved trees in well-aerated waters and introduced the taxa Alatospora acuminata, Anguillospora longissima ( $\equiv$ Amniculicola longissima), Articulospora tetracladia ( $\equiv$ Hymenoscyphus tetracladius), Clavariopsis aquatica, Flagellospora curvula, Heliscus aquaticus (三 Nectria lugdunensis), Heliscus longibrachiatus (三 Clavatospora longibrachiata), Lemonniera aquatica, Lunulospora curvula, Margaritispora aquatica, Tetracladium marchalianum, Tetrachaetum elegans, Tetracladium setigerum, Tricladium angulatum, Tricladium splendens, Varicosporium elodeae, almost 50 years after Wildeman observed their conidial morphology. At the time, Ingold was studying chytrids in a stream behind his house, and coincidentally found a large fungal spore collection trapped in scum behind a barrier of twigs (Bärlocher 1992). After a long experimental period, he discovered their structure and detailed 16 species of which ten were novel (Ingold 1942, 1953). Ainsworth (1976) considered this discovery as a "minor mycological industry" as the discovery of Ingold paved the way for an era where reports of the fungal occurrence multiplied. Presently, these hyphomycetes are popularly known as Ingoldian fungi, in honour of C.T. Ingold (Webster \& Descals 1981a, b). Ingoldian fungi were previously known as "aquatic hyphomycetes" (de Wildeman 1895, Ingold 1942), freshwater hyphomycetes (Nilsson 1964), and "amphibious hyphomycetes" (Michaelides \& Kendrick 1978). In the 1950s, Ingold (Ingold 1951, 1954, 1955) noted that aquatic ascomycetes were abundant in freshwater particularly on stalks of reed swamp plants with many of the ascospores with variously developed appendages (e.g. Ceriospora caudae-suis, Loramyces macrospora). A vast number of comprehensive studies were published after the initial work of Ingold (Ranzoni, 1953, Tubaki 1957, Petersen 1962, 1963a, b, Nilsson 1964, Webster \& Descals 1981a, b, Dudka 1985, Goh \& Hyde 1996, Chan et al. 2000, Sivichai et al. 2000, 2006, Pinnoi et al. 2006). Since Ingold's early research, numerous studies, both on sexual and asexual taxa, have been published from all over the world (Tubaki et al. 1983, Hyde 1992, Sridhar et al. 1992, Jones et al. 1999, Hyde \& Wong 2000, Tsui et al. 2001b, Tsui \& Hyde 2003, Pinruan et al. 2004, Shearer et al. 2004, 2007, 2014, Zhang et al. 2011, Liu et al. 2015). The most recent major publications on freshwater ascomycetes and hyphomycetes are from Shearer et al. (2014), Luo et al. (2019) and Dong et al. (2020), while those on Ingoldian fungi on leaves are by Chan et al. (2000), Selosse et al. (2008), Sudheep \& Sridhar (2013), Ghate \& Sridhar (2015), Fiuza et al. (2017), Fiuza et al. (2019) and Tarda et al. (2019).

\section{Ecology}

Freshwater fungi can be saprobes, mutualists and parasites (Cole et al. 1990, Wong et al. 1998, Ibelings et al. 2004, Schulz \& Boyle 2005, Sati \& Belwal 2005, Seena et al. 2008, Kohout et al. 2012, Masclaux et al. 2013, Karun et al. 2016, Ghate \& Sridhar 2017). All these relationships are important for the decomposition process in freshwater systems. Furthermore, the fungal niches overlap with niches of different organisms such as plankton, invertebrates, insects, and fish thriving in freshwater habitats leading to direct and indirect influence of the former (Ibelings et al. 2004, Shearer et al. 2007, Roa et al. 2009, Sudheep \& Sridhar 2011, Jones et al. 2014a, Gleason et al. 2014, Glockling et al. 2014, Powell \& Letcher 2014).

Freshwater fungi play a key role in the transfer of nutrients and flow of energy between trophic levels in the food web by breaking down complex organic compounds into simpler inorganic materials of dead flora and fauna (Kaushik \& Hynes 1971, Chamier 1985, Raviraja et al. 1996, Wong et al. 1998, Sridhar \& Bärlocher 2000, Abdel-Raheem \& Shearer 2002, Krauss et al. 2011, Sridhar et al. 2013, Wurzbacher et al. 2014, Tsui et al. 2016). Most aquatic fungi can decompose a wide range of organic substrates, although a few species are limited to one or a few types of substrates (Tsui et al. 2016). Most aquatic hyphomycetes can degrade cellulose, various hemicelluloses and pectins (Chamier 1985, Zemek et al. 1985, Chandrashekar \& Kaveriappa 1991, Abdel-Raheem \& Shearer 2002). Aquatic hyphomycetes also aid the decomposition of plant materials into detritus by producing exoenzymes that increases the palatability of substrates for shredders and collectors (Bärlocher \& Kendrick 1974, Anderson \& Sedell 1979, Cummins \& Klug 
1979, Tsui et al. 2016). In general, Ingoldian fungi are thought to decompose either leaves or herbaceous debris while ascomycetes and basidiomycetes break down woody debris (Jones 1972, 1973, Boonyuen et al. 2014). Zoosporic fungi are colonizers of smaller substrates which contain chitin, keratin or cellulose (Wong et al. 1998). Chytrids are responsible for the decomposition of small particles such as algae, zooplankton carcasses, seeds and pollen grains including other temporarily available smaller substrates (Tsui et al. 2016).

Shearer (1995) reviewed different methods used to study fungal competition and discussed the ways in which freshwater fungi defended or gained space on submerged substrates. Precolonization was used to determine the ability of one species to influence fungal community structure by manipulating the abundance of one or more hypothetically competing species. There are few reports on the interspecific competition among fungal species in freshwater habitats and the results suggest that the pre-colonization appears to influence the subsequent colonization of fungi on substrates (Shearer \& Bartolata 1990, Sridhar \& Bärlocher 1993, Fryar et al. 2001).

Few aquatic fungi form a symbiotic mycorrhizal relationship with the roots of trees and other plants and macrophytes. The latter provides nutrition for the fungus, and the former enables the plant to take up unavailable nutrients (see Søndergaard \& Laegaard 1977, Seena et al. 2008, Sudová et al. 2011, Kohout et al. 2012). Some aquatic hyphomycetes have been reported as endophytes, but it is unclear if the effect on plant hosts is harmful or beneficial (Sati \& Belwal 2005, Schulz \& Boyle 2005). Most chytrid species are benign saprobes, but they often occur as parasites, sometimes as symbionts, and of course as decomposers (Ibelings et al. 2004). Mutualistic relationships of freshwater fungi with living hosts were observed in Trichomycetes growing in the gut of insects, crustaceans and millipedes that often breed in discrete and disjunct lentic habitats (Lichtwardt \& Williams 1999, Roa et al. 2009, Lichtwardt 2014). For example, Smittium culisetae found in the hindgut of Aedes aegypti larvae could serve as a source of essential elements for insect growth, primarily of sterols and B-vitamin (Horn \& Lichtwardt 1981, Lichtwardt et al. 2003). Mutualistic Trichomycetes may improve the assimilation of recalcitrant compounds directly in the gut of their hosts (Suberkropp et al. 1983). Studies on freshwater fungi with mutualistic relationships with living hosts are scarce due to their cryptic presence (e.g. some Trichomycetes belonging to Asellariales and Eccrinales remain unculturable) and related methodological difficulties (Lichtwardt et al. 2003).

Fungi can release different types of gases (e.g. $\mathrm{CO}_{2}, \mathrm{~N}_{2}, \mathrm{~N}_{2} \mathrm{O}$, volatile gases) into the surrounding environment (see Palmer et al. 1997, Fourest \& Volesky 1997, Gulis et al. 2006). In addition, fungi act in the same role as aquatic plants for the phytoremediation process in the aquatic ecosystems (see Say et al. 2001, López \& Vazquez 2003, Anand et al. 2006, Singh 2006, Iskandar et al. 2011, Harms et al. 2011, Anastasi et al. 2013). Saprobic fungi on dead particles have the potential to secrete chemicals on the substrate to induce their metabolism (see Chamier \& Dixon 1982a, b, Chamier et al. 1984, Crawford 1981, Kirk et al. 1977, Singh 1982, Suberkropp \& Klug 1980, Chamier 1985, Junghanns et al. 2005, Cabana et al. 2007, Solé et al. 2012, Tsui et al. 2016). Furthermore, some parasitic, endophytic and competitive fungi also secrete various chemicals to enhance their functions. These antibacterial, nematicidal, antifungal, bio-surfactant and detoxifying compounds are economically and ecologically important (Wong et al. 1998, Ho et al. 2003, Hernández-Carlos \& Gamboa-Angulo 2011, Singh \& Sati 2020).

The geographical distribution of freshwater fungi may be restricted to tropical, temperate, or cold-water habitats, while others are cosmopolitan (Tsui \& Hyde 2003, Duarte et al. 2012, Tsui et al. 2016). Several papers reported shifts in fungal communities and taxonomic composition by latitude, altitude, $\mathrm{pH}$, season, turbulence, riparian vegetation, temperature and the length of time that the substrate has been submerged (see Webster \& Descals 1981a, b, Wood-Eggenschwiler \& Bärlocher 1985, Gönczöl 1989, Shearer \& Webster 1985, 1991, Raviraja et al. 1998, Arnold \& Lutzoni 2007, Tsui et al. 2001a, Raja et al. 2009, Boonyuen et al. 2014, Hyde et al. 2016, da Silva et al 2019, Fiuza et al. 2019).

The relationship between freshwater fungi and adjacent terrestrial fungal assemblages is poorly understood. In studies that have sampled the same substrates in adjacent freshwater and 
terrestrial habitats, there has been low overlap in the species present and different dominant species (Wellbaum et al. 1999, Cai et al. 2006b Pinruan et al. 2007, Kodsueb et al. 2016). Although some freshwater species are found in terrestrial habitats (Bandoni 1972, Swe et al. 2009), most are only found in freshwater (Révay \& Gönczöl 2011). Kodsueb et al. (2016) carried out succession studies where they placed terrestrial branches in streams and recollected them at 3 and 6 months. There was a change from terrestrial taxa to only freshwater taxa within that period. Jones \& Oliver (1964) observed colonization of aquatic hyphomycetes after 6 weeks of submersion of wood test blocks/panels. Kane et al. (2002) and Sivichai et al. (2000) submerged test panels in freshwater and followed their colonization over 12 months. Sporulating fungi were observed after four weeks suggesting that samples are not examined early enough in such studies with some escaping detection. Future studies should employ high throughput sequencing of the substrates over time, starting within a few hours to establish how soon fungi colonize substrates in freshwater habitats.

\section{Sexual-asexual connections of freshwater hyphomycetes}

Studies documenting sexual-asexual connections have also revealed many links between the sexual morphs and freshwater hyphomycetes (Sivichai \& Jones 2003, Hu et al. 2014, Sati \& Pathak 2016, Tanney \& Miller 2017, Luo et al. 2019). In 2016, there were over 300 species of extant aquatic hyphomycetes and $15 \%$ of them were linked to their sexual morphs (Sati \& Pathak 2016). $\mathrm{Hu}$ et al. (2014) listed 77 connections of aquatic hyphomycetes to their sexual states. The number of linked morphs is now much higher and thus a further reason for developing the website so that these links can be documented in one platform.

\section{Classification of freshwater fungi}

\section{Freshwater ascomycetes}

Freshwater ascomycetes are found on fully or partly submerged substrates in freshwater habitats (Shearer 1993). Jones et al. (2014a) reported 622 species ( 200 genera) of Ascomycota. Freshwater ascomycetes are composed of Arthoniomycetes, Chaetothyriomycetes, Dothideomycetes, Eurotiomycetes, Laboulbeniomycetes, Lecanoromycetes, Lecanoromycetes incertae sedis, Leotiomycetes, Lichinomycetes, Sordariomycetes, and Pezizomycetes (Jones et al. 2014a).

\section{Freshwater Dothideomycetes}

The freshwater Dothideomycetes comprise one third (200 species) of freshwater Ascomycota (Shearer et al. 2009). The ascostromatic fruit body and bitunicate asci often with fissitunicate dehiscence characterize this class (Hyde et al. 2013). Dothideomycetous species constitute a large group in freshwater environments and are generally isolated from submerged wood or bamboo (Zhang et al. 2012, Dong et al. 2020). The phylogenetic analysis of freshwater Dothideomycetes by Shearer et al. (2014) include 14 families in Pleosporales, of which ten accepted in Pleosporales incertae sedis. Jahnulales, Natipusillales and Minutisphaera clades were classified as Dothideomycetes incertae sedis. These numbers will increase as new species, genera, families and orders are being introduced (Ariyawansa et al. 2015, Raja et al. 2015, Lu et al. 2018a, b, Bao et al. 2019a, b, Boonmee et al. 2019, Calabon et al. 2020a, b, c, Boonmee et al. 2020, Dong et al. 2020, Hyde et al. 2020a, Li et al. 2020). For example, Wicklowiaceae was introduced by Ariyawansa et al. (2015) to accommodate Wicklowia. The Minutisphaeria clade was placed in Minutisphaerales, an order introduced by Raja et al. (2015) wherein two families, Acrogenosporaceae and Minutisphaeraceae (type), are accepted. The latest classification and morphological study of freshwater Dothideomycetes were by Dong et al. (2020). Dong et al. (2020) listed all the freshwater species belonging to six orders, 43 families, 145 genera in Dothideomycetes and reviewed all genera with a description, illustration, notes, freshwater distribution and a key. Among Dothideomycetes, 46 genera were unique to freshwater habitats (Dong et al. 2020). 


\section{Freshwater Sordariomycetes}

Sordariomycetes are the second largest group of freshwater Ascomycota. The class is characterized by non-lichenized, perithecial ascomata and inoperculate unitunicate (Zhang et al. 2006, Kirk et al. 2008, Luo et al. 2019). Shearer \& Raja (2010) reported 307 species of freshwater Sordariomycetes, nearly half of known freshwater Ascomycota at that time, which was 622 species. In a phylogenetic study, Cai et al. (2014) showed that freshwater Sordariomycetes are distributed in 13 orders (Calosphaeriales, Coniochaetales, Diaporthales, Halosphaeriales, Hypocreales, Magnaporthales, Microascales, Ophiostomatales, Phyllachorales, Savoryellales, Sordariales, Trichosphaeriales and Xylariales) under three subclasses, Sordariomycetidae, Hypocreomycetidae and Xylariomycetidae. The number has increased as new species, genera, families and orders have been introduced from freshwater habitats (Marin-Felix et al. 2018, Yang 2019, Luo et al. 2019, Boonmee et al. 2020, Hyde et al. 2020a). Luo et al. (2019) provided a comprehensive monograph of freshwater Sordariomycetes and introduced one new order (Distoseptisporales), two new families (Ceratosphaeriaceae, Triadelphiaceae), three new genera (Aquafiliformis, Dematiosporium, Neospadicoides), 47 new species, two new combinations and nine new records. This was incorporated in the Refined Families of Sordariomycetes (Hyde et al. 2020b) and Outline of Fungi and fungus-like taxa (Wijayawardene et al. 2020).

\section{Freshwater ascomycetous yeasts}

Ascomycetous yeasts are common inhabitants of freshwater environments, including damp mines, lakes, rivers, tundra ponds, glacial melts, and can tolerate extreme environmental conditions (Libkind et al. 2014). The most speciose order is Saccharomycetales with the genera Candida (e.g. C. antarcticus isolated from cold water stream), Kodamaea (e.g. K. ohmeri isolated from tropical lakes and rivers, Brazil) and Mrakiella (e.g. M. aquatica isolated from a lake freshwater foam, UK), and Pichia (e.g. P. kluveri isolated from Shark River, USA). Freshwater ascomycetous yeasts are less well-documented than freshwater basidiomycete yeasts.

\section{Freshwater basidiomycetes}

Basidiomycetes in freshwater habitats are taxonomically diverse including both saprobic yeasts and filamentous forms, and endophytes. Freshwater basidiomycetes thrive on various substrates such as wood (e.g. Limnoperdon incarnatum, Mycocalia reticulata, Stauriella aquatica, Psathyrell aquatica which has typical agaricoid fruit body), culms (e.g. Mrakiella aquatica), trapped in foam (e.g. Crucella subtilis, Taeniospora gracilis) and isolated from water columns (Cryptococcus spp., Rhodotorula spp.) (Jones \& Slooff 1966, Marvanová 1977, Marvanová \& Suberkropp 1990, Hyde \& Goh 1998, Sivichai \& Jones 2004, Brandăo et al. 2011, Fell et al. 2011). Jones et al. (2014b) listed 115 species of freshwater basidiomycetes belonging to 50 genera, eight classes and 19 orders. Freshwater basidiomycetes include Ingoldian fungi such as Crucella subtilis, Ingoldiella hamata, Naiadella fluitans and Taeniospora descalsii with their known sexual morph Camptobasidium hydrophilum (Camptobasidiales), Sistotrema hamatum (Cantharellales), Classicula fluitans (Classiculales) and Leptosporomyces crucelliger (Atheliales) (Nawawi \& Webster 1982, Marvanová \& Bandoni 1987, Marvanová \& Stalpers 1987, Marvanová \& Suberkropp 1990, Bauer et al. 2003, Bernicchia \& Gorjón 2010). The yeast form has the highest number of species comprising $64.35 \%$ (74 species) of the total freshwater basidiomycetes. Tremellomycetes has the highest number of species (41 species, 12 genera, five orders). The most speciose order is Tremellales with 27 species under the genera Bullera $(2$ species: B. dendrophila, B. sinensis), Cryptococcus (20 species: C. albidus, C. adeliensis, C. agrionensis, C. cistialbidi, C. cylindricus, C. carnescens, C. diffluens, C. gastricus, C. gilvescens, $C$. heveanensis, C. laurentii, C. magnus, C. saitoi, C. spencermartinsiae, C. stepposus, C. taeanensis, C. tephrensis, C. terreus, C. victoriae, C. wieringae), Dioszegia (4 species: D. crocea, D. fristingensis, D. hungarica, D. zsoltii) and Xenolachne (one species: X. flagellifera). 


\section{Freshwater Chytridiomycetes}

Chytridiomycota is characterized by posteriorly uniflagellate zoospores which function in the dispersal of the fungus to new substrates or hosts. Most freshwater chytrids are parasitic on algae, especially plankton (Canter \& Lund 1968), while others are parasites of animals: amphibians frogs/toads (Batrachochytrium dendrobatidis, B. salamandrivorans, Longcore et al. 1999). Many are found exclusively in freshwater and are clearly freshwater fungi, but some isolated from soil, dung and detritus in tree canopies (Wakefield et al. 2010, Simmons et al. 2012, Longcore 2005). Powell \& Letcher (2014) discussed the phylogeny and characterization of freshwater Chytridiomycota. Two classes constitute freshwater chytrids, Chytridiomycetes (nine orders, 97 genera, 946 species) and Monoblepharidomycetes (one order, six genera, 50 species). The most speciose order is Chytridiales, and constitutes of 385 species under two families: Chytridiaceae (four genera: Chytridium, Dendrochytridium, Polyphyctis, Phylctochytrium), and Chytriomycetaceae (12 genera: Asterophlyctis, Avachytrium, Chytriomyces, Entophlyctis, Obelidium, Odontochytrium, Phylctorhiza, Physocladia, Podochytirum, Rhizidium, Rhizoclosmatium, Siphonaria), two Incertae sedis (Delfinachytrium, Pseudorhizidium).

\section{Freshwater Blastocladiomycota}

Blastocladiomycota, posteriorly uniflagellated zoosporic fungi, commonly found as saprotrophs and parasites of fungi, algae, plants and invertebrates of soil and freshwater, and sometimes found to be facultatively anaerobic (Sparrow 1960, Hibbett et al. 2007, James et al. 2006a, b, 2014, Powell 2017). Wijayawardene et al. (2018b) accepted two classes (Blastocladiomycetes, Physodermatomycetes) three orders (Blastocladiales, Callimastigales, Catenomycetales), eight families (Blastocladiaceae, Callimastigaceae, Catenariaceae, Catenomycetaceae, Coelomomycetaceae, Paraphysodermataceae, Physodermataceae, Porochytriaceae) and 14 genera (Allomyces, Blastocladia, Blastocladiopsis, Callimastix, Catenomyces, Catenophlyctis, Coelomomyces, Coelomycidium, Endoblastidium, Microallomyces, Nematoceromyces, Paraphysoderma, Physoderma, Sorochytrium) in Blastocladiomycota. Tedersoo et al. (2018) introduced the subkingdom Blastocladiomyceta and subphylum Blastocladiomycotina. All of these, except Endoblastidium, were reported from freshwater habitats (Hanson et al. 1945, Vavra \& Joyon 1966, Sparrow 1968, Held et al. 1969, Liu \& Volz 1977, Vincent 1988, El-Hissy et al. 1996, McCreadie \& Adler 1999, Kiziewicz 2004, Steciow \& Marano 2006, Gutman et al. 2009, Porter et al. 2011, Doweld 2014, Glockling et al. 2014, James et al. 2014, Powell 2017, Swafford \& Oakley 2018, Wijayawardene et al. 2018b, Wijayawardene et al. 2020).

\section{Freshwater Rozellomyceta (Class Microsporidia)}

Of all the freshwater fungi, the least known and poorly documented are the microsporidia and require good optics for their detection. Microsporidia are spore-forming obligate intracellular parasites of eukaryotic hosts such as bony fish (Osteichyes), and arthropods (Kearney \& Gleason 2014). Microsporidial spores possess a polar tube which can pierce a host cell, depositing the parasite's sporoplasm within the host cell and consumes host organelles (Larsson 1999). The sporoplasm proliferates to produce spores which are discharged to infect new hosts. Classification is based on morphology, light and electron microscopy and sequence data (ITS gene). Microsporidial classification is by referral to their generic names.

\section{Aphelidiomycota, Monoblepharomycota, Mortierellomycota}

Tedersoo et al. (2016) proposed a new classification which accepted Rozellomycota and Aphelidiomycota as phyla in the kingdom fungi. Karpov et al. (2014) describe the Aphelidiomycota as "opisthokont intracellular parasitoids of algae with phagotrophic amoeboid vegetative stage; invasive cyst with a short infective tube of penetration apparatus; zoospores with pseudopodia and/or posteriorly directed functional or rudimentary flagellum". The genera Amoeboaphelidium (five species), Aphelidium (seven species), Paraphelidium (two species), Pseudaphelidium (one species) composed in the monotypic phylum (Tedersoo et al. 2018, 
Wijayawardene et al. 2020). Aphelidium, Amoeboaphelidium, and Paraphelidium thrive in freshwater environments (Zopf 1885, Scherffel 1925, Schweikert \& Schnepf 1996, Karpov et al. 2017, Letcher \& Powell 2019).

Monoblepharomycota was introduced by Doweld (2001) based on Monoblepharis and accepted by Tedersoo et al. (2016), who proposed another class, Sanchytriomycetes, in the phylum. Three classes (Hyaloraphidiomycetes, Monoblepharidomycetes, Sanchytriomycetes), three orders (Hyaloraphidiales, Monoblepharidales, Sanchytriales), seven families (Gonapodyaceae, Harpochytriaceae, Hyaloraphidiaceae, Monoblepharidaceae, Oedogoniomycetaceae, Sanchytriaceae, Telasphaerulaceae) and seven genera (Gonapodya, Harpochytrium, Hyaloraphidium, Monoblepharella, Monoblepharis, Oedogoniomyces, Telasphaerula) are included in Monoblepharomycota (Wijayawardene et al. 2020). All of these genera are found in freshwater habitats (Jane 1946, Karpov et al. 2017, Wijayawardene et al. 2018b).

Mortierellomycota was upgraded to a phylum level by Tedersoo et al. (2016) and comprised one class (Mortierellomycetes), one order (Mortierellales), one family (Mortierellaceae) and six genera (Aquamortierella, Dissophora, Gamsiella, Lobosporangium, Modicella, Mortierella). Only Aquamortierella and Mortierella are known to thrive in freshwater habitats (Embree \& Indoh 1967, Nguyen \& Lee 2016, Nguyen et al. 2019, Wijayawardene et al. 2018b).

\section{Need for a freshwater fungi website}

Online databases are developed to compile data for general accounts of fungi (e.g. http://www.indexfungorum.org; http://www.speciesfungorum.org/; http://www.mycobank.org; http://www.facesoffungi.org; http://www.fungalgenera.org, https://www.outlineoffungi.org/), or even certain ecological (e.g. http://marinefungi.org for marine fungi; http://fungi.life.illinois.edu/ for freshwater ascomycetes and their anamorphs) and taxonomic groups (e.g. Dothideomycetes: http://www.dothideomycetes.org; $\quad$ Sordariomycetes: http://www.sordariomycetes.org; coelomycetes: http://www.coelomycetes.org; basidiomycetes: https://www.basidio.org). Of all the websites mentioned, the webpage http://fungi.life.illinois.edu/ focuses only on freshwater fungi. With the advent of molecular techniques and the continuous exploration of different freshwater habitats and substrates, new species, even the existing ones lacking DNA sequence data, are discovered that could change the classification scheme at certain taxonomic level, or fungal systematics as a whole. Thus, the online database for freshwater fungi, www.freshwaterfungi.org, is developed to compile all the scattered published data on freshwater fungi using a user-friendly interface and is freely accessible to public users.

The website focuses on three primary goals: (1) to provide an up-to-date outline of the freshwater fungi; (2) to give detailed notes on orders, families and genera of freshwater fungi; (3) to give an updated account of each genus keeping abreast of the current literature. The website has a valuable list of references, history and news regarding freshwater fungi.

\section{Freshwater fungi website}

The website is dedicated to the taxonomy and classification of the freshwater fungi. For speciose genera, only the description of the type species is initially provided, with a synopsis table of all the freshwater species. The rule applies to those genera whose type species were first recorded in freshwater habitats. Otherwise, if the type species is from marine or terrestrial environment, the first introduced freshwater fungus with molecular sequence data is described and the remaining freshwater species enumerated. Freshwater genera with only two or three species records will be added to the website. Once the genera and type species of all the classes are added, the remaining freshwater species will be described over time. All accounts on the taxonomy and phylogeny of freshwater fungi will be updated on the notes for each taxonomic level- from class to species. This is true to species without molecular sequence data and when the taxonomic placement is already known.

For each genus, a detailed description of the species with photographic plates, phylogenetic trees for those with molecular sequence data, and keys for more than two species are provided. The 
website is linked to other online databases to expand the current knowledge of freshwater fungi namely, the "Fungal Genera", (https://www.fungalgenera.org; Monkai et al. 2019), "Outline of Fungi" (https://www.outlineoffungi.org/, Wijayawardene et al. 2020), "Faces of Fungi" (http://www.facesoffungi.org; Jayasiri et al. 2015), marine fungi (http://www.marinefungi.org; Jones et al. 2019), Dothideomycetes (https://www.dothideomycetes.org/, Pem et al. 2019), Sordariomycetes (https://sordariomycetes.org/, Bundhun et al. 2020), basidiomycetes (https://basidio.org/) and coelomycetes (https://coelomycetes.org/).

We encourage all mycologists to contribute to this web page over time and it will provide a complete one stop shop where details of freshwater fungal genera and species, molecular data as well as their roles, biosecurity issues, economic significance and industrial relevance can be sourced.

\section{Construction}

Freshwater fungi included in the website are outlined according to the most recent classification of Ascomycota (Wijayawardene et al. 2017, 2018a, 2020, Hyde et al. 2020b, Luo et al. 2019), Basidiomycota (He et al. 2019), and basal fungi (= lower fungi) (Wijayawardene et al. $2018 \mathrm{~b}, 2020)$. The current account of Sordariomycetes and Dothideomycetes on the website follows the current outline of Luo et al. (2019) and Dong et al. (2020), respectively. The description of the species entries follows the Fungal Diversity Notes (FDN) format (Phookamsak et al. 2019). The outline, detailed description and notes of each entry in the website are carefully checked by the curators (Table 2).

Table 2 List of expert curators with their information for freshwater fungi webpage

\begin{tabular}{|c|c|c|c|}
\hline Position & Name & Address & Contact information \\
\hline Head Curator & Saranyaphat Boonmee & $\begin{array}{l}\text { Center of Excellence in Fungal } \\
\text { Research (CEFR), Mae Fah Luang } \\
\text { University, 57100, Chiang Rai, } \\
\text { Thailand }\end{array}$ & saranyaphat.boo@mfu.ac.th \\
\hline \multirow[t]{2}{*}{$\begin{array}{l}\text { Managing } \\
\text { Curators }\end{array}$} & Sajini Chandrasiri & $\begin{array}{l}\text { Center of Excellence in Fungal } \\
\text { Research (CEFR), Mae Fah Luang } \\
\text { University, 57100, Chiang Rai, } \\
\text { Thailand }\end{array}$ & sajinichandrasiri@yahoo.com \\
\hline & Mark S. Calabon & $\begin{array}{l}\text { Center of Excellence in Fungal } \\
\text { Research (CEFR), Mae Fah Luang } \\
\text { University, 57100, Chiang Rai, } \\
\text { Thailand }\end{array}$ & mscalabon@up.edu.ph \\
\hline \multirow[t]{5}{*}{ Curators } & Dan-Feng Bao & $\begin{array}{l}\text { Center of Excellence in Fungal } \\
\text { Research (CEFR), Mae Fah Luang } \\
\text { University, 57100, Chiang Rai, } \\
\text { Thailand }\end{array}$ & baodanfengfungi@qq.com \\
\hline & Wei Dong & $\begin{array}{l}\text { Institute of Plant Health, Zhongkai } \\
\text { University of Agriculture and } \\
\text { Engineering, Guangzhou, Guangdong } \\
\text { Province, People's Republic of China }\end{array}$ & dongwei0312@hotmail.com \\
\hline & Sally Fryar & $\begin{array}{l}\text { College of Science and Engineering, } \\
\text { Flinders University, GPO Box } 2100 \text {, } \\
\text { Adelaide SA 5001, Australia }\end{array}$ & sally.fryar@flinders.edu.au \\
\hline & Kevin D. Hyde & $\begin{array}{l}\text { Center of Excellence in Fungal } \\
\text { Research (CEFR), Mae Fah Luang } \\
\text { University, 57100, Chiang Rai, } \\
\text { Thailand }\end{array}$ & kdhyde3@gmail.com \\
\hline & E.B. Gareth Jones & $\begin{array}{l}\text { Department of Botany and } \\
\text { Microbiology, College of Science, } \\
\text { King Saud University, P.O. Box 2455, } \\
\text { Riyadh 11451, Kingdom of Saudi } \\
\text { Arabia }\end{array}$ & torperadgj@gmail.com \\
\hline
\end{tabular}


Table 2 Continued.

\begin{tabular}{cll}
\hline \multicolumn{1}{c}{ Name } & \multicolumn{1}{c}{ Address } & \multicolumn{1}{c}{ Contact information } \\
\hline Yong-Zhong Lu & School of Pharmaceutical & yzlu86@gmail.com \\
& Engineering, Guizhou Institute of & \\
& Technology, Guiyang, 550003, & \\
& Guizhou, China & \\
& College of Agriculture and Biological & luozonglongfungi@163.com \\
& Sciences, Dali University, Dali, & \\
& 671003, People's Republic of China & \\
& Center of Excellence in Fungal & yangjing5633@gmail.com \\
& Research (CEFR), Mae Fah Luang & \\
& University, 57100, Chiang Rai, & \\
& Thailand & \\
&
\end{tabular}

\section{Database interface and visualization}

www.freshwaterfungi.org is an online platform that compiles published information on the classification and taxonomy of freshwater fungi. The website's interface is simple and user-friendly (Fig. 1). The heading provides the eight features and functions of the website. The general information of the webpage, the contact information (email address: freshwaterfungi.org@gmail.com; address: Mushroom Research Foundation, 292 Moo 18 Bandu District Muang Chiang Rai, 57100 Thailand) and the publisher (Mushroom Research Foundation) is located at the footer of the webpage. The left side of the webpage lists all recent uploaded genera and species. The search toolbar is found above the Recent Genus of the webpage. To find the genus or taxon of interest, input the information in the search box and a pop-up suggestion appears with the target fungi including its taxonomic level (Fig. 2). Clicking on the species name will direct you to the description, notes, photographic plates and phylogenetic tree of freshwater fungi (Fig. 3). The references used in the description and notes are linked to its original source to obtain information about the species.

The website has eight different features and functions in the uppermost part. First, the Home tab provides the ultimate goals of the webpage, the general and specific information the website offers, and a photo slideshow of selected freshwater fungi (Fig. 1). The Outline provides the recent classification at all taxonomic levels of freshwater fungi (Fig. 4). Some species are automatically linked to their information on the website. The following typographical symbols are used in the website as additional information of the species in the outline: an asterisk $\left(^{*}\right)$ if the species has available molecular sequence data; type of habitat, + (plus) sign if the fungus is isolated in the lotic environment, and hyphen (-) if found in the lentic. Number (\#) sign is added to species with sexual or asexual connections. The type of habitat where the species is isolated and if possible, the host where the fungus is associated or is recorded after the author's name. The updated information including the descriptions, notes, photographic plates and phylogenetic tree of the specific order and families are listed in the Archives (Fig. 5). The Curators section provides the contact information and the affiliated institutions of all the curators of the website. A short historical background of freshwater mycology is on the History tab. The References is a compilation of all the published work (e.g. books, reviews, monographs and articles) on freshwater fungi. For the current year, all the available information about freshwater mycology is separated from the alphabetical list of all the references in the tab. This is to show the volume of research works done on that particular year. All activities and news related to mycology are shown in the News. The Contact tab gives the public users of the website to address any comments, suggestions and even entries. 


\section{ISSN $* * * * \ldots * * *$}

Freshwaterfungi.org is a website dedicated to the taxonomy and classification of freshwater fungi. The website focuses on three primary goals.

1) To provide an up-to-date outline of the freshwater fungi

2) To provide notes on orders, families and genera of freshwater fung

3) To provide updated accounts of each genus keeping abreast of the current literature. The website will also provide a list of references dealing with freshwater fungi.

Citation for webpage:

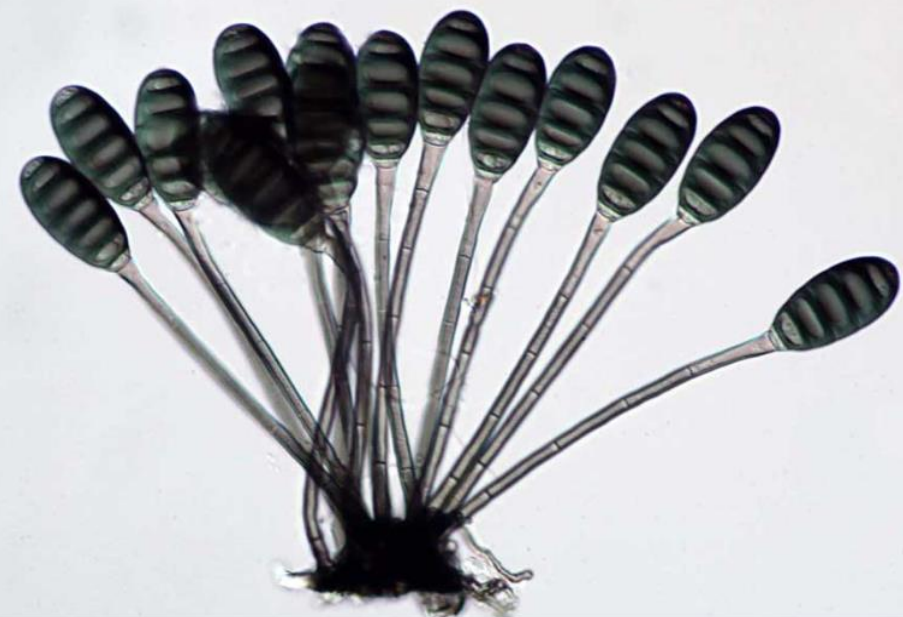

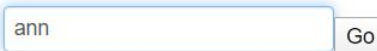

\section{Recent Genus}

Longicollum

Submersisphaeria Ophioceras

Recent Species

Longicollum biappendiculatum Submersisphaeria aquatica Ophioceras dolichostomum

Fig. 1 - The homepage view of the freshwater fungi containing a short background of the website, the highlight of information, a photo slideshow, and the different features and functions including the search toolbar and recent uploaded data.

Freshwaterfungi.org is a website dedicated to the taxonomy and classification of freshwater fungi. The website focuses on three primary goals.

1) To provide an up-to-date outline of the freshwater fungi

2) To provide notes on orders, families and genera of freshwater fung

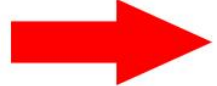

3) To provide updated accounts of each genus keeping abreast of the current literature. The website will also provide a list of references dealin with freshwater fungi.

\section{Citation for webpage:}

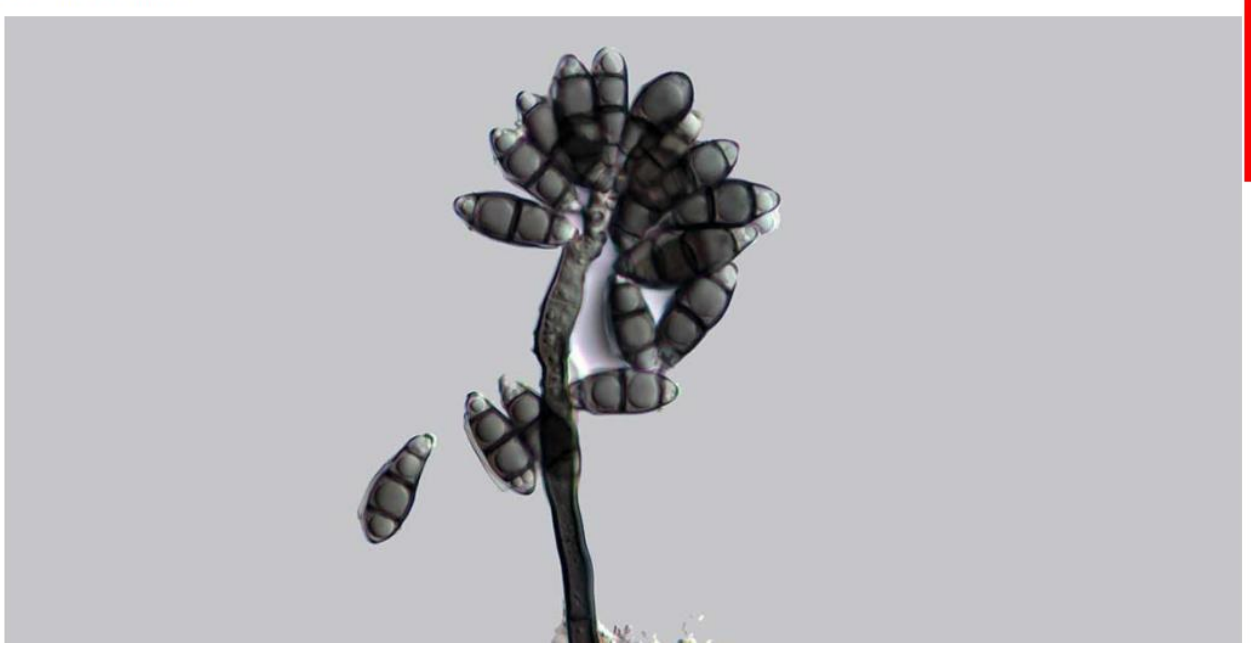

\begin{tabular}{|l|l|}
\hline annl & Go \\
\hline Orders & \\
\hline Annulatascales & \\
\hline Family & \\
\hline Annulatascaceae & \\
Genus & \\
Annulatascus & \\
Annulusmagnus & \\
\hline Species & \\
\hline Annulatascus velatisporus & \\
Annulusmagnus triseptatus & \\
\hline
\end{tabular}

Fig. 2 - The search toolbar of the website showing some suggestions of the fungi of interest based on the user's data inputs. 
ISSN *********

Magnaporthales» Ophioceraceae Ophioceras

Ophioceras dolichostomum

Recent Genus

Ophioceras dolichostomum (Berk. \& M.A. Curtis)

Index Fungorum number: 146613

Sexual morph: Ascomata immersed, lenticular to conical, ostiolate, beaked, black, solitary or gregarious. Neck long, black, periphysate. Paraphyses laonger than asci, persistence, hyaline, septate, tapering, $16 \mu \mathrm{m}$, at the base, $4 \mathrm{\mu m}$ at the tip, formed of cells up to $50 \mu \mathrm{m}$ long. Asci 116-132 × 8-10 $\mu \mathrm{m}$, 8-spored, cylindrical, short pedunculate, unitunicate, thin-walled, with a non-amyloid ring-like apical apparatus, 3.2- 4 um long $\times 24-32 \mu \mathrm{m}$ wide. Ascospores 90-104 × 25-3.5 um, 4-6. celled, hyaline in mass, filform, straight or slightly curved or twisted in the ascus, curved on release, rounded and both end and lacking mucilage. Asexual morph: Undetermined.

Longicollum

Submersisphaeria

Ophioceras

Recent Species

Longicollum biappendiculatum

Submersisphaeria aquatica

Ophioceras dolichostomum

Specimen examined: AUSTRALIA, north Queensland, submerged wood (Hyde1992b); JAPAN. Koito River, on submerged wood (Tsui et al.2001a): USA. Florida, on submerged wood (Conway and Barr1977); SEYCHELLES, Riviere St Marie-Louis, on submerged wood (Hyde and Goh1998a).

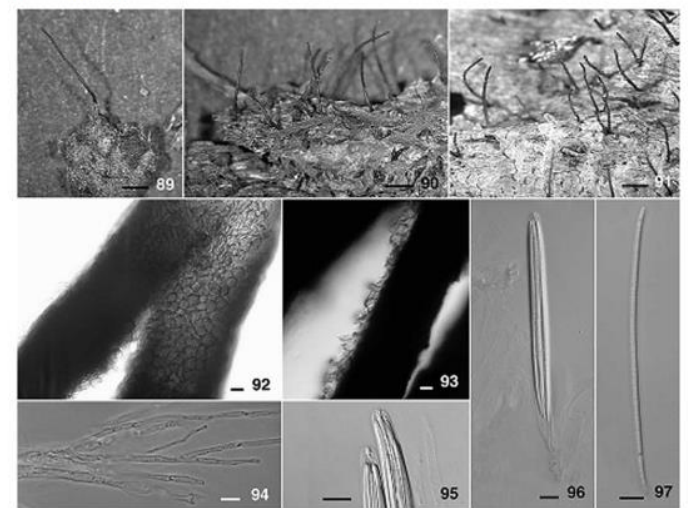

Fig 1. Ophioceras dolichostomum. No. 89-91. Ascomata on the substrate. No. 92, 93. Ascomatal neck surface. No. 94. Paraphyses. No 95. Ascus apices with rings. No. 96. Ascus. No. 97 . Ascospores. No. 89-91 by photomicrography; No. 92, 93, 95-97 by DIC; 94 by PH Scale bars: $89-91=1 \mu \mathrm{m}, 92-97=10 \mu \mathrm{m} .89,90$ from NY isotype; $91-97$ from SMH1888. (Photo grabbed from Huhndorf et.al 2008)

References

Hyde KD. (1992) Tropical Australian Freshwater Fungi. IV. Halosarpheia aquatica sp. nov., Garethjonesia lacunosispora gen. \& sp. nov, and Ophioceras dolichostomum (Ascomycetes). Aust. Syst. Bot. 5, 407-414

Shearer CA. Crane JL and Chen W. (1999) Freshwater Ascomycetes: Ophioceras Species. Mycological Society of America 91, 145-156 Huhndorf SM, Greif M, Mugambi GK, Miller AN. (2008) Two new genera in the Magnaporthaceae, a new addition to Ceratosphaeria and two new species of Lentomitella. Mycologia. 100, 940-955

Fig. 3 - A detailed description with illustration of fungi Ophioceras dolichostomum.

Outline

$Q \rightarrow \leftarrow 4$

Outline of Freshwater Sordariomycetes

$\begin{array}{ll}\text { Phylum: } & \text { ASCOMYCOTA } \\ \text { Subphylum: } & \text { Pezizomycotina } \\ \text { Class: } & \text { Sordariomycetes } \\ \text { Subclass: } & \text { Diaporthomycetidae Senan et al. } \\ \text { Order: } & \text { Annulatascales D'souza et al. } \\ \text { Family: } & \text { Annulatascaceae Wong et al. } \\ & \text { Annulatascus K.D. Hyde } \\ & \text { Annulatascus apiculatus F.R. Barbosa \& Gusmão } \\ & \text { Annulatascus aquaticus Ho et al. } \\ & \text { Annulatascus aquatorba Boonyuen \& Sri-indrasutdhi } \\ & \text { Annulatascus fusiformis K.D. Hyde \& S.W. Wong } \\ & \text { Annulatascus hongkongensis Ho et al. } \\ & \text { Annulatascus joannae Tsui et al. } \\ & \text { Annulatascus liputii L. Cai \& K. K. Hyde } \\ & \text { Annulatascus menglensis Hu et al. } \\ & \text { Annulatascus nilensis Abdel-Wahab \& Abdel-Aziz } \\ & \text { Annulatascus palmietensis Goh et al. } \\ & \text { Annulatascus saprophyticus Z. L. Luo \& K.D. Hyde } \\ & \text { Annulatascus tropicalis Ranghoo \& K.D. Hyde } \\ & \text { Annulatascus velatisporus K.D. Hyde }\end{array}$

Annulusmagnus J Campb \& Shearer

Annulusmagnus triseptatus (Wong et al.) J. Campb. \& Shearer

Aqualignicola Ranghoo et al.

Aqualignicola hyalina Ranghoo et al.

Aqualignicola vaginata $\mathrm{Hu}$ et al.

Ascitendus J. Campb. \& Sheare

Ascitendus aquaticus Dayarathne et al.

Ascitendus austriacus (Réblová et al.) J. Campb. \& Shearer

Search Go

Recent Genus

Longicollum

Submersisphaeria

Recent Species

Longicollum biappendiculatum

Submersisphaeria aquatica

Fig. 4 - An outline of freshwater Sordariomycetes based on Luo et al. (2019) 


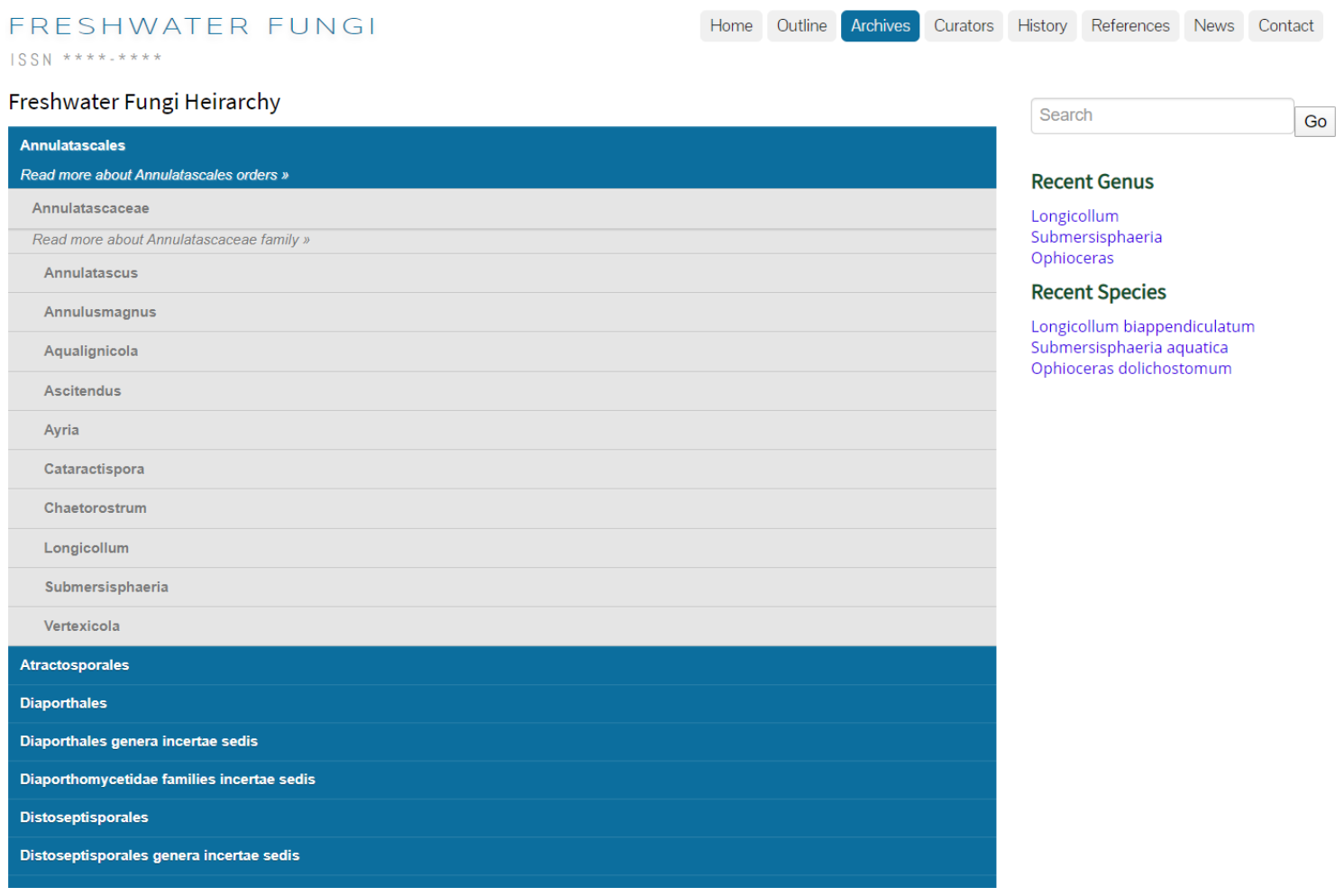

Fig. 5 - The Archive tab with the outline of the orders and families of freshwater fungi. These are all linked in the description of each orders and families.

\section{Acknowledgment}

MS Calabon is grateful to the Mushroom Research Foundation and the Department of Science and Technology- Science Education Institute (Philippines). Saranyaphat Boonmee would like to thank the Thailand Research Fund (No. TRG6180001) and Plant Genetic Conservation Project under the Royal Initiation of Her Royal Highness Princess Maha Chakri Sirindhorn - Mae Fah Luang University. Kevin D. Hyde thanks the Thailand Research Fund grant entitled "Impact of climate change on fungal diversity and biogeography in the Greater Mekong Subregion" (Grant No: RDG6130001). E. B. Gareth Jones is supported under the Distinguished Scientist Fellowship Program (DSFP), King Saud University, Kingdom of Saudi Arabia.

\section{References}

Abdel-Raheem A, Shearer CA. 2002 - Extracellular enzyme production by freshwater ascomycetes. Fungal Diversity 11, 1-19.

Ainsworth GC. 1976 - Introduction to the history of mycology, 1st ed. Cambridge University Press, Cambridge.

Anand P, Isar J, Saran S, Saxena RK. 2006 - Bioaccumulation of copper by Trichoderma viride. Bioresource Technology 97, 1018-1025.

Anastasi A, Tigini V, Varese GC. 2013 - The bioremediation potential of different ecophysiological groups of fungi. In: Goltapeh EM, Danesh YZ, Varma A, eds. Fungi as bioremediators. Berlin: Springer 29-49.

Anderson NH, Sedell JR. 1979 - Detritus processing by macroinvertebrates in stream ecosystems. Annual Review of Entomology 24, 351-377.

Ariyawansa HA, Hyde KD, Jayasiri SC, Buyck B et al. 2015 - Fungal diversity notes 111-252taxonomic and phylogenetic contributions to fungal taxa. Fungal Diversity 75, 27-274.

Arnold AE, Lutzoni F. 2007 - Diversity and host range of foliar fungal endophytes: Are tropical leaves biodiversity hotspots? Ecology 88, 541-549. 
Ballie B, Collier K, Halliday J. 1998 - Woody debris in pumice-bed-streams - how long does it last and its use by aquatic insects. LIRO Reports 23, 1-5.

Bandoni R. 1972 - Terrestrial occurrence of some aquatic hyphomycetes. Canadian Journal of Botany 50, 2283-2288.

Bao DF, Hyde KD, Luo ZL, Su HY et al. 2019a - Minutisphaera aquaticum sp. nov. increases the known diversity of Minutisphaeraceae. Asian Journal of Mycology 2, 306-314.

Bao DF, Su HY, Maharachchikumbura SSN, Liu JK et al. 2019b - Lignicolous freshwater fungi from China and Thailand: Multi-gene phylogeny reveals new species and new records in Lophiostomataceae. Mycosphere 10, 1080-1099.

Bärlocher F, Kendrick B. 1974 - Dynamics of the fungal population on leaves in a stream. The Journal of Ecology 62, 761-791.

Bärlocher F, Sridhar KR. 2014 - Association of animals and fungi in leaf decomposition. In: Jones EBG, Hyde KD, Pang KL, eds. Freshwater fungi and fungal-like organisms. Berlin: Walter de Gruyter 413-442.

Bärlocher F. 1992 - Research on aquatic hyphomycetes: Historical background and overview. In: Bärlocher F, ed. The ecology of aquatic hyphomycetes. Berlin: Springer-Verlag 1-15.

Bärlocher F. 2010 - Molecular approaches promise a deeper and broader understanding of the evolutionary ecology of aquatic hyphomycetes. Journal of the North American Benthological Society 29, 1027-1041.

Bauer R, Begerow D, Oberwinkler F, Marvanová L. 2003 - Classicula: The teleomorph of Naiadella fluitans. Mycologia 95, 756-764.

Bernicchia A, Gorjón SP. 2010 - Fungi Europaei. Corticiaceae s.1. Edizioni Candussolia, Alassio.

Boonmee S, Calabon MS, Huanraluek N, Rossi W et al. 2020 - Fungal diversity notes 1390-1455: taxonomic and phylogenetic contributions on genera and species of fungal taxa. Fungal Diversity (in press).

Boonmee S, Sorvongxay T, Huanraluek N, Hyde KD. 2019 - Wicklowia submersa sp. nov. (Wicklowiaceae, Pleosporales), a second species in a monotypic family. Phytotaxa 411, 7383.

Boonyuen N, Sivichai S, Jones EBG. 2014 - Decomposition of wood in tropical habitats. In: Jones EBG, Hyde KD, Pang KL, eds. Freshwater fungi and fungal-like organisms. Berlin: Walter de Gruyter 465-480.

Branda E, Turchetti B, Diolaiuti G, Pecci M et al. 2010 - Yeast and yeast-like diversity in the southernmost glacier of Europe (Calderone Glacier, Apennines, Italy). FEMS Microbiology Ecology 72, 354-369.

Brandăo LR, Rosa CA, Medeiros AO. 2011 - Yeast diversity in freshwater ecosystems. In: Daniels JA, ed. Advances in Environmental Research. Hauppauge: Science Publisher Inc. 207-222.

Brutschy A. 1927 - Tetracladium marchalianum de Wildeman. Ein nur wenig beachteter Wasserpilz. Mikrokosmos 21, 145-146.

Bundhun D, Maharachchikumbura SSN, Jeewon R, Senanayake IC et al. 2020 https://sordariomycetes.org/, a platform for the identification, ranking and classification of taxa within Sordariomycetes. Asian Journal of Mycology 3, 13-21.

Buzzini P, Branda E, Goretti M, Turchetti B. 2012 - Psychrophilic yeasts from worldwide glacial habitats: diversity, adaptation strategies and biotechnological potential. FEMS Microbiology Ecology 82, 217-241.

Buzzini P, Turchetti B, Diolaiuti G, D'Agata C. 2005 - Culturable yeasts in meltwaters draining from two glaciers in the Italian Alps. Annals of Glaciology 40, 119-122.

Cabana H, Jones JP, Agathos SN. 2007 - Elimination of endocrine disrupting chemicals using white rot fungi and their lignin modifying enzymes: A review. Engineering in Life Sciences 7, 429-456.

Cai L, Hu DM, Liu F, Hyde KD, Jones EBG. 2014 - The molecular phylogeny of freshwater Sordariomycetes and discomycetes. In: Jones EBG, Hyde KD, Pang KL, eds. Freshwater fungi and fungal-like organisms. Berlin: Walter de Gruyter 47-72. 
Cai L, Hyde KD, Tsui CKM, Gadgil PD. 2006a - Genera of Freshwater Fungi. Hongkong: Fungal Diversity Press.

Cai L, Ji KF, Hyde KD. 2006b - Variation between freshwater and terrestrial fungal communities on decaying bamboo culms. Antonie Van Leeuwenhoek 89, 293-301.

Calabon MS, Hyde KD, Gentekaki E, Jones EBG et al. 2020a - Wicklowia phuketensis (Wicklowiaceae, Pleosporales), a novel freshwater taxon from Thailand. Phytotaxa 452, 5564.

Calabon MS, Hyde KD, Jones EBG, Doilom M et al. 2020b - Mycoenterolobium aquadictyosporium sp. nov. (Pleosporomycetidae, Dothideomycetes) from a freshwater habitat in Thailand. Mycological Progress (in press).

Calabon MS, Jones EBJ, Hyde KD, Boonmee S et al. 2020c - Phylogenetic assessment and taxonomic revision of Halobyssothecium and Lentithecium (Lentitheciaceae, Pleosporales). Mycological Progress (in press).

Canter HM, Lund JWG. 1968 - The importance of Protozoa in controlling the abundance of planktonic algae in lakes. Proceedings of the Linnean Society of London 179, 203-219

Chamier AC, Dixon PA, Archer SA. 1984 - The spatial distribution of fungi on decomposing alder leaves in a freshwater stream. Oecologia 64, 92-103.

Chamier A-C, Dixon PA. 1982a - Pectinases in leaf degradation by aquatic hyphomycetes: the field study. The colonization- pattern of aquatic hyphomycetes on leaf packs in a Surrey stream. Oecologia 52, 109-115.

Chamier A-C, Dixon PA. 1982b - Pectinases in leaf degradation by aquatic hyphomycetes: the enzymes and leaf maceration. Journal of General Microbiology 128, 2469-2483.

Chamier ACC. 1985 - Cell-wall-degrading enzymes of aquatic hyphomycetes: a review. Botanical Journal of the Linnaean Society 91, 67-81.

Chan SY, Goh TK, Hyde KD. 2000 - Ingoldian fungi in Hong Kong. Fungal Diversity 5, 89-107.

Chandrashekar KR, Kaveriappa KM. 1991 - Production of extracellular cellulase by Lunulospora curvula and Flagellospora penicillioides. Folia Microbiologica 36, 249-255.

Chandrashekar KR, Sridhar KR, Kaveriappa KM. 1991 - Aquatic hyphomycetes of a sulphur spring, India. Hydrobiologia 218, 151-156.

Chauvet E, Cornut J, Sridhar KR, Sélosse MA, Bärlocher F. 2016 - Beyond the water column: Aquatic hyphomycetes outside their preferred habitats. Fungal Ecology 19, 112-127.

Choi JJ, Kim SH. 2017 - A genome Tree of Life for the Fungi kingdom. Proceedings of the National Academy of Sciences of the United States of America USA 114, 9391-9396.

Cole JJ, Caraco NF, Likens GE. 1990 - Short-range atmospheric transport - a significant source of phosphorus to an Oligotrophic Lake. Limnology and Oceanography 35, 1230-1237.

Crawford RL. 1981 - Lignin biodegradation and transformation. Wiley Intersci, New York.

Cummins KW, Klug MJ. 1979 - Feeding ecology of stream invertebrates. Annual Review of Ecology and Systematics 10, 147-172.

da Silva GVR, Castañeda-Ruiz RF, Malosso E. 2019 - Comparison of aquatic hyphomycetes communities between lotic and lentic environments in the Atlantic rain forest of Pernambuco, Northeast Brazil. Fungal Biology 123, 660-668.

de Garcia V, Brizzio S, Libkind D, Buzzini P, van Broock M. 2007 - Biodiversity of cold-adapted yeasts from glacial meltwater rivers in Patagonia, Argentina. FEMS Microbiology Ecology 59, 331-341.

de Wildeman E. 1893 - Notes mycologiques. Fasc II Ann Soc Belge Microscopie 17, 35-68.

de Wildeman E. 1894 - Notes mycologiques. Fasc III Ann Soc Belge Microscopie 18, 135-161.

de Wildeman E. 1895 - Notes mycologiques. Fasc II Ann Soc Belge Microscopie 19: 193-206.

Dong WW, Wang B, Hyde KD, McKenzie EHC et al. 2020 - Freshwater Dothideomycetes. Fungal Diversity (in press).

Doweld AB. 2001 - Prosyllabus tracheophytorum tentamen systematis plantarum vascularium (Tracheophyta). Geos, Moscow.

Doweld AB. 2014 - Nomenclatural novelties. Index Fungorum 48, 1-1. 
Duarte S, Bärlocher F, Trabulo J, Cássio F, Pascoal C. 2015 - Stream-dwelling fungal decomposer communities along a gradient of eutrophication unraveled by 454 pyrosequencing. Fungal Diversity 70, 127-148.

Duarte S, Seena S, Bärlocher F, Cássio F, Pascoal C. 2012 - Preliminary insights into the phylogeography of six aquatic hyphomycete species. PLoS One 7, e45289.

Dudka IA. 1985 - Aquatic Fungi imperfecti from the Soviet Union. Ukrainian Academy of Science, Kiev.

Eaton RA, Jones EBG. 1970 - New fungi on timber from water-cooling towers. Nova Hedwigia 19, 779-786.

Eaton RA, Jones EBG. 1971a - The biodeterioration of timber in water cooling towers I. Fungal ecology and decay of wood at Connah's Quay and Ince. Material Und Organismen 6, 51-80.

Eaton RA, Jones EBG. 1971b - The biodeterioration of timber in water cooling towers II. Fungi growing on wood in different positions in a water-cooling system. Material Und Organismen 6, 81-92.

El-Hissy FT, Moharram AM, El-Zayat SA, Massoud MS. 1996 - Aquatic phycomycetes recovered from Aswan High Dam Lake [AHDL]. Microbiological Research 151, 149-156.

Embree RW, Indoh H. 1967 - Aquamortierella, a new genus in the Mucorales. Bulletin of the Torrey Botanical Club 94, 464.

Fell JW, Statzell-Tallman A, Scorzetti G, Gutiérrez MH. 2011 - Five new species of yeasts from fresh water and marine habitats in the Florida Everglades. Antonie Leeuwenhoek 99, 533549.

Fisher PJ. 1977 - New methods of detecting and studying saprophytic behaviour of aero-aquatic hyphomycetes from stagnant water. Transactions of the British Mycological Society 68, 407411.

Fiuza PO, Cantillo-Pérez T, Gulis V, Gusmão LFP. 2017 - Ingoldian fungi of Brazil: Some new records and a review including a checklist and a key. Phytotaxa 306, 171-200.

Fiuza PO, Costa LA, Medeiros AO, Gulis V et al. 2019 - Diversity of freshwater hyphomycetes associated with leaf litter of Calophyllum brasiliense in streams of the semiarid region of Brazil. Mycological Progress 18, 907-920.

Fourest E, Volesky B. 1997 - Alginate properties and heavy metal biosorption by marine algae. Applied Biochemistry and Biotechnology - Part A Enzyme Engineering and Biotechnology 67, 260-264.

Fragoso GR. 1920 - Nuevo genero y especie de hifal sobre hojas de Sphagnum. Boletín de la Real Sociedad Española de Historia Natural 20, 112-114.

Fryar SC, Yuen TK, Hyde KD, Hodgkiss IJ. 2001 - The influence of competition between tropical fungi on wood colonization in streams. Microbial Ecology 41, 245-251.

Gadanho M, Libkind D, Sampaio JP. 2006 - Yeast diversity in the extreme acidic environments of the Iberian Pyrite Belt. Microbial Ecology 52, 552-563.

Gadanho M, Sampaio JP. 2006 - Microeukaryotic diversity in the extreme environments of the Iberian Pyrite Belt: a comparison between universal and fungi-specific primer sets, temperature gradient gel electrophoresis and cloning. FEMS Microbiology Ecology 57, 139148.

Gessner MO, Van Ryckegem G. 2002 - Fungal decomposers in freshwater ecosystems. In: Bitton G, ed. Encyclopedia of Environmental Microbiology. New York: Wiley 1-20.

Ghate SD, Sridhar KR. 2015 - Diversity of aquatic hyphomycetes in sediments of temporary streamlets of Southwest India. Fungal Ecology 14, 53-61.

Ghate SD, Sridhar KR. 2017 - Endophytic aquatic hyphomycetes in roots of riparian tree species of two Western Ghat streams. Symbiosis 71, 233-240.

Ghate SD, Sridhar KR. 2018 - Aquatic and aeroaquatic fungal spores in urban runoff of southwest India. KAVAKA - Transactions of the Mycological Society of India 51, 23-29. 
Gleason FH, Jephcott TG, Küpper FC, Gerphagnon M et al. 2015 - Potential roles for recently discovered chytrid parasites in the dynamics of harmful algal blooms. Fungal Biology Reviews 29, 20-33.

Gleason FH, Lilje O, Marano AV, Sime-Ngando T et al. 2014 - Ecological functions of zoosporic hyperparasites. Frontiers in Microbiology 5, 244

Glockling SL, Marano AV, Lilje O, Gleason FH. 2014 - Zoosporic parasites of freshwater invertebrates. In: Jones EBG, Hyde KD, Pang KL, eds. Freshwater fungi and fungal-like organisms. Berlin: Walter de Gruyter 305-330.

Goh TK, Hyde KD. 1996 - Biodiversity of freshwater fungi. Journal of Industrial Microbiology and Biotechnology 17, 328-345.

Gönczöl J. 1989 - Longitudinal distribution patterns of aquatic hyphomycetes in a mountain stream in Hungary - experiments with leaf packs. Nova Hedwigia 48, 391-404.

Grossart HP, Van den Wyngaert S, Kagami M, Wurzbacher C et al. 2019 - Fungi in aquatic ecosystems. Nature Reviews Microbiology 17, 339-354.

Grove WB. 1912 - New or noteworthy fungi - Part IV. The London Journal of Botany 50, 9-18.

Gulis V, Kuehn K, Suberkropp K. 2006 - The role of fungi in carbon and nitrogen cycles in freshwater ecosystems. In: Gadd G, ed. Fungi in biogeochemical cycles. Cambridge: Cambridge University Press 404-435.

Gutman J, Zarka A, Boussiba S. 2009 - The host-range of Paraphysoderma sedebokerensis, a chytrid that infects Haematococcus pluvialis. European Journal of Phycology 44, 509-514.

Hanson AM. 1945 - A morphological, developmental, and cytological study of four saprophytic chytrids. I. Catenomyces persicinus Hanson. American Journal of Botany 32, 431-438.

Harms H, Schlosser D, Wick LY. 2011 - Untapped potential: Exploiting fungi in bioremediation of hazardous chemicals. Nature Reviews Microbiology 9, 177-192.

He M, Zhao R, Hyde KD, Begerow D et al. 2019 - Notes, outline and divergence times of Basidiomycota. Fungal Diversity 99, 105-367.

Held AA, Emerson R, Fuller MS, Gleason FH. 1969 - Blastocladia and Aqualinderella: Fermentative water molds with high carbon dioxide optima. Science 165, 706-708.

Hernández-Carlos B, Gamboa-Angulo MM. 2011 - Metabolites from freshwater aquatic microalgae and fungi as potential natural pesticides. Phytochemistry Reviews 10, 261-286.

Hibbett DS, Binder M, Bischoff JF, Blackwell M et al. 2007 - A higher-level phylogenetic classification of the Fungi. Mycological Research 111: 509-547.

Ho WH, To PC, Hyde KD. 2003 - Induction of antibiotic production of freshwater fungi using mix-culture fermentation. Fungal Diversity 12, 45-51.

Hongsanan S, Hyde KD, Phookamsak R, Wanasinghe DN et al. 2020 - Refined families of Sordariomycetes. Fungal Diversity (in press).

Hongsanan S, Maharachchikumbura SSN, Hyde KD, Samarakoon MC et al. 2017 - An updated phylogeny of Sordariomycetes based on phylogenetic and molecular clock evidence. Fungal Diversity 84, 25-41.

Horn BW, Lichtwardt RW. 1981 - Studies on the nutritional relationship of larval Aedes aegypti (Diptera: Culicidae) with Smittium culisetae (Trichomycetes). Mycologia 73, 724-740.

Hu DM, Cai L, Jones EBG, Zhang H et al. 2014 - Taxonomy of filamentous asexual fungi from freshwater habitats, links to sexual morphs and their phylogeny. In: Jones EBG, Hyde KD, Pang KL, eds. Freshwater fungi and fungal-like organisms. Berlin: Walter de Gruyter 109132.

Huber-Pestalozzi G. 1925 - Zur Morphologie und Entwicklungsgeschichte von Asterothrix (Cerasterias) raphidioides (Rheinsch) Printz. Hedwigia 65, 169-178.

Huber-Pestalozzi G. 1938 - Das Phytoplankton des Süsswassers. Schweizerbart'sche Verlagsbuchhandlung, Stuttgart.

Hyde KD. 1992 - Tropical Australian freshwater fungi. II* Annulatascus velatispora gen. et sp. nov., A. bipolaris sp. nov. and Nais aquatica sp. nov. (ascomycetes). Australian Systematic Botany 5, 117-124. 
Hyde KD, Dong Y, Phookamsak R, Jeewon R et al. 2020a - Fungal diversity notes 1151-1276: taxonomic and phylogenetic contributions on genera and species of fungal taxa. Fungal Divers 100:5-277. Doi 10.1007/s13225-020-00439-5

Hyde KD, Fryar S, Tian Q, Jeewon R et al. 2016 - Lignicolous freshwater fungi along a northsouth latitudinal gradient in the Asian/Australian region; can we predict the impact of global warming on biodiversity and function? Fungal Ecology 19, 190-200.

Hyde KD, Goh WH. 1998 - Fungi on submerged wood in Lake Barrine, North Queensland, Australia. Mycological Research 102, 739-749.

Hyde KD, Jones EBG, Liu JK, Ariyawansa H et al. 2013 - Families of Dothideomycetes. Fungal Diversity 63, 1-313.

Hyde KD, Norphanphoun C, Maharachchikumbura SSN, Bhat DJ et al. 2020b - Refined families of Sordariomycetes. Mycosphere 11, 305-1059.

Hyde KD, Wong SW. 2000 - Annulatascus fusiformis sp. nov., a new freshwater ascomycete from the Philippines. Mycologia 92, 553-557.

Hyde KD, Wong SW, Jones EBG. 1997 - Freshwater ascomycetes. In: Hyde KD, ed. Biodiversity of tropical microfungi. Hong Kong, Hong Kong University Press 179-187.

Ibelings BW, De Bruin A, Kagami M, Rijkeboer M et al. 2004 - Host parasite interactions between freshwater phytoplankton and chytrid fungi (Chytridiomycota). Journal of Phycology 40, 437-453.

Ibelings BW, Gsell AS, Mooij WM, Van Donk E et al. 2011 - Chytrid infections and diatom spring blooms: Paradoxical effects of climate warming on fungal epidemics in lakes. Freshwater Biology 56, 754-766.

Ingold CT. 1942 - Aquatic hyphomycetes of decaying alder leaves. Transactions of the British Mycological Society 25, 339-417.

Ingold CT. 1951 - Aquatic ascomycetes: Ceriospora caudae-suis n.sp. and Ophiobolus typhae. Transactions of the British Mycological Society 34, 210-215.

Ingold CT. 1953 - Dispersal in fungi. Oxford University Press, Oxford.

Ingold CT. 1954 - Aquatic ascomycetes: Discomycetes from lakes. Transactions of the British Mycological Society 37, 1-18.

Ingold CT. 1955 - Aquatic ascomycetes: further species from the English Lake District. Transactions of the British Mycological Society 38, 157-168.

Iskandar NL, Zainudin NAIM, Tan SG. 2011 - Tolerance and biosorption of copper $(\mathrm{Cu})$ and lead $\mathrm{Pb})$ by filamentous fungi isolated from a freshwater ecosystem. Journal of Environmental Sciences 23, 824-830.

Ittner LD, Junghans M, Werner I. 2018 - Aquatic fungi: a disregarded trophic level in ecological risk assessment of organic fungicides. Frontiers in Environmental Science 6, 105.

James TY, Kauff F, Schoch CL, Matheny PB et al. 2006a - Reconstructing the early evolution of Fungi using a six-gene phylogeny. Nature 443, 818-822.

James TY, Letcher PM, Longcore JE, Mozley-Standridge SE et al. 2006b - A molecular phylogeny of the flagellated fungi (Chytridiomycota) and description of a new phylum (Blastocladiomycota). Mycologia 98, 860-871.

James TY, Porter TM, Martin WW. 2014 - Blastocladiomycota. In: McLaughlin DJ, Spatafora JW, eds. The Mycota VII Part A. New York: Springer 177-207.

Jane FW. 1946 - A revision of the genus Harpochytrium. Journal of the Linnean Society of London, Botany 53, 28-40.

Jayasiri SC, Hyde KD, Ariyawansa HA, Bhat J et al. 2015 - The Faces of Fungi database: fungal names linked with morphology, phylogeny and human impacts. Fungal Diversity 74, 3-18.

Jayawardena RS, McKenzie EHC, Chen YJ, Phillips AJL et al. 2019 https://onestopshopfungi.org/, a database to enhance identification of phytopathogenic genera. Asian Journal of Mycology 2, 281-286.

Jobard M, Rasconi S, Sime-Ngando T. 2010 - Diversity and functions of microscopic fungi: A missing component in pelagic food webs. Aquatic Sciences 72, 255-268. 
Jones EBG. 1972 - The decay of timber in aquatic environments; British Wood Preserving Association, Annual Convention.

Jones EBG. 1973 - Aquatic fungi: freshwater and marine. In: Dickinson CH, Pugh GFJ, eds. Biology of plant litter decomposition. New York: Academic Press 337-383.

Jones EBG. 1976 - Recent advances in aquatic mycology. Halsted Press, New York.

Jones EBG. 1981 - Observations on the ecology of lignicolous aquatic hyphomycetes. In: Wicklow DT, Carroll GC, eds. The Fungal Community. New York: Marck-Dekker 191-212.

Jones EBG, Eaton RA. 1969 - Savoryella lignicola gen. et sp. nov. from water cooling towers. Transactions of the British Mycological Society 52, 161-174.

Jones EBG, Hyde KD, Pang KL. 2014a - Freshwater fungi and fungal-like organisms. Walter de Gruyter, Berlin.

Jones EBG, Oliver AC. 1964 - Occurrence of aquatic hyphomycetes on wood submerged in fresh and brackish water. Transactions of the British Mycological Society 47, 45-48.

Jones EBG, Pang KL, Abdel-Wahab MA, Scholz B et al. 2019 - An online resource for marine fungi. Fungal Diversity 96, 347-433.

Jones EBG, Slooff WC. 1966 - Candida aquatica sp. nov. isolated from water scums. Antonie Leeuvenhoek 32, 223-228.

Jones EBG, Southworth D, Libkind D, Marvanová L. 2014b - Freshwater Basidiomycota. In: Jones EBG, Hyde KD, Pang KL, eds. Freshwater fungi and fungal-like organisms. Berlin: Walter de Gruyter 73-108.

Jones EBG, Wong SW, Sivichai S, Au DWT, Hywel-Jones NL. 1999 - Lignicolous freshwater Ascomycota from Thailand: Micropeltopsis quinquecladiopsis sp. nov. Mycological Research 103, 729-735.

Junghanns C, Moeder M, Krauss G, Martin C, Schlosser D. 2005 - Degradation of the xenoestrogen nonylphenol by aquatic fungi and their laccases. Microbiology 151, 45-57.

Kane DF, Tam WY, Jones EBG. 2002 - Fungi colonising and sporulating on submerged wood in the River Severn, UK. In: Hyde KD, Jones EBG, eds. Fungal Succession. Hongkong: Fungal Diversity Press 45-55.

Karpov SA, Mamkaeva MA, Aleoshin VV, Nassonova E et al. 2014 -Morphology, phylogeny and ecology of the aphelids (Aphelidea, Opisthokonta) and proposal for the new superphylum Opisthosporidia. Frontiers in Microbiology 5, 112.

Karpov SA, Tcvetkova VS, Mamkaeva MA, Torruella G. 2017 - Morphological and genetic diversity of Opisthosporidia: New new Aphelid aphelid Paraphelidium tribonemae gen. et sp. nov. Journal of Eukaryotic Microbiology 64, 204-212.

Karun NC, Sridhar KR, Ghate SD. 2016 - Aquatic hyphomycetes in detritus, sediment, and water in the Western Ghat streams. KAVAKA - Transactions of the Mycological Society of India 47, 107-113.

Kaushik NK, Hynes HBN. 1971 - The fate of the dead leaves that fall into streams. Archiv Fur Hydrobiologie 68, 597-607.

Kearney R, Gleason FH. 2014 - Microsporidia. In: Jones EBG, Hyde KD, Pang KL, eds. Freshwater fungi and fungal-like organisms. Berlin: Walter de Gruyter 157-176.

Kegel W. 1906 - Varicosporium elodeae, ein Wasserpilz mit auffallender Konidienbildung. Berichte der Deutschen Botanischen Gesellschaft 24, 213-216.

Kirk PM, Cannon, PF, Minter DW, Stalpers JA. 2008 - Ainsworth \& Bisby's dictionary of the fungi, $10^{\text {th }}$ edn. CAB International, Wallingford.

Kirk TK, Connors WJ, Zeikus JG. 1977 - Advances in understanding the microbial degradation of lignin. In: Loewus FA, Runeckles VS, eds. Recent advances in phytochemistry vol. 11. New York: Plenum Press 369-394.

Kiziewicz B. 2004 - Water fungi occurence in the water reservoir in Zarzeczany of Podlasie province. Wiadomości Parazytologiczne 50, 587-593.

Kodsueb R, Lumyong S, McKenzie EHC, Bahkali AH, Hyde KD. 2016 - Relationships between terrestrial and freshwater lignicolous fungi. Fungal Ecology 19, 155-168. 
Kohout P, Sýkorová Z, Čtvrtlíková M, Rydlová J et al. 2012 - Surprising spectra of root-associated fungi in submerged aquatic plants. FEMS Microbiology Ecology 80, 216-235.

Krauss G, Solé M, Krauss G, Schlosser D et al. 2011 - Fungi in freshwaters: ecology, physiology and biochemical potential. FEMS Microbiology Reviews 35, 620-651.

Larsson JIR. 1999 - Identification of Microsporidia. Acta Protozoologica 38, 161-197.

Letcher PM, Powell MJ. 2019 - A taxonomic summary of Aphelidiaceae. IMA Fungus 10, 4.

Li WJ, McKenzie EHC, Liu JK, Bhat DJ et al. 2020 - Taxonomy and phylogeny of hyaline-spored coelomycetes. Fungal Diversity 100, 279-801.

Libkind D, Brizzio S, van Broock M. 2004 - Rhodotorula mucilaginosa, a carotenoid producing yeast strain from Patagonian high-altitude lake. Folia Microbiologica 49, 19-25.

Libkind D, Russo G, van Broock MR. 2014 - Yeasts from extreme aquatic environments: hyperacidic freshwaters. In: Jones EBG, Hyde KD, Pang KL, eds. Freshwater fungi and fungal-like organisms. Berlin: Walter de Gruyter 443-464.

Lichtwardt RW. 2014 - Aquatic Trichomycetes. In: Jones EBG, Hyde KD, Pang KL, eds. Freshwater fungi and fungal-like organisms. Berlin: Walter de Gruyter 359-370.

Lichtwardt RW, White MM, Cafaro MJ. 2003 - Freshwater trichomycetes and their arthropod hosts. In: Tsui CKM, Hyde KD, eds. Freshwater mycology. Fungal Diversity Research Series 10. Hong Kong: Fungal Diversity 81-100.

Lichtwardt RW, Williams MC. 1999 - Three Harpellales that live in one species of aquatic chironomid larva. Mycologia 91, 396-399.

Liu CH, Volz PA. 1977 - Freshwater fungi of Taiwan. Mycologia 69, 1079-1081.

Liu XY, Udayanga D, Luo ZL, Chen LJ et al. 2015 - Backbone tree for Chaetothyriales with four new species of Minimelanolocus from aquatic habitats. Fungal Biology 119, 1046-1062.

Longcore JE, Pessier AP, Nichols DK. 1999 - Batrachochytrium dendrobatidis gen. et sp. nov., a chytrid pathogenic to amphibians. Mycologia 91, 219-227.

Longcore JE. 2005 - Zoosporic fungi from Australian and New Zealand tree-canopy detritus. Australian Journal of Botany 53, 259-272.

López EE, Vázquez C. 2003 - Tolerance and uptake of heavy metals by Trichoderma atroviride isolated from sludge. Chemosphere 50, 37-143.

López-Archilla AI, Marín I, Amils R. 2001 - Microbial community composition and ecology of an acidic aquatic environment: the Tinto River, Spain. Microbial Ecology 41, 20-35.

Lowe CW. 1927 - Cerasterias, the child of sorrow of the algologist. Transactions of the Royal Society of Canada 21, C111.

Lu YZ, Liu JK, Hyde KD, Rajesh J et al. 2018a - A taxonomic reassessment of Tubeufiales based on multi-locus phylogeny and morphology. Fungal Diversity 92, 131-344.

Lu YZ, Boonmee S, Liu JK, Hyde KD et al. 2018b - Multi-gene phylogenetic analyses reveals Neohelicosporium gen. nov. and five new species of helicosporous hyphomycetes from aquatic habitats. Mycological Progress 17, 631-646.

Luo ZL, Hyde KD, Liu JK, Maharachchikumbura SSN et al. 2019 - Freshwater Sordariomycetes. Fungal Diversity 99, 451-660.

Maharachchikumbura SSN, Hyde KD, Jones EBG, McKenzie EHC et al. 2015 - Towards a natural classification and backbone tree for Sordariomycetes. Fungal Diversity 72, 199-301.

Maharachchikumbura SSN, Hyde KD, Jones EBG, McKenzie EHC et al. 2016 - Families of Sordariomycetes. Fungal Diversity 79, 1-317.

Marin-Felix Y, Guarro J, Cano-Lira JF, García D et al. 2018 - Melanospora (Sordariomycetes, Ascomycota) and its relatives. MycoKeys 44, 81-122.

Marvanová L, Bandoni RJ. 1987 - Naiadella fluitans gen. et sp. nov.: A conidial basidiomycete. Mycologia 79, 578-586.

Marvanová L, Stalpers JA. 1987 - The genus Taeniospora and its teleomorphs. Transactions of the British Mycological Society 89, 489-498.

Marvanová L, Suberkropp K. 1990 - Camptobasidium hydrophilum and its anamorph, Crucella subtilis: A new heterobasidiomycete from streams. Mycologia 82, 208-217. 
Marvanová L. 1977 - Taeniospora gracilis gen. et sp. nov. Transactions of the British Mycological Society 69, 146-148.

Masclaux H, Perga ME, Kagami M, Desvilettes C et al. 2013 - How pollen organic matter enters freshwater food webs. Limnology and Oceanography 58, 1185-1195.

McCreadie JW, Adler PH. 1999 - Parasites of larval black flies (Diptera: Simuliidae) and environmental factors associated with their distributions. Invertebrate Biology 118, 310-318.

Michaelides J, Kendrick B. 1978 - An investigation of factors retarding colonization of conifer needles by amphibious hyphomycetes in streams. Mycologia 70, 419-430.

Monkai J, McKenzie EHC, Phillips AJL, Hongsanan S et al. 2019 - https://fungalgenera.org/: a comprehensive database providing web-based information for all fungal genera. Asian Journal of Mycology 2, 298-305.

Nakatsu C, Hutchinson TC. 1988 - Extreme metal and acid tolerance of Euglena mutabilis and an associated yeast from Smoking Hills, Northwest territories, and their apparent mutualism. Microbial Ecology 16, 213-231.

Naranjo-Ortiz MA, Gabaldón T. 2019 - Fungal evolution: diversity, taxonomy and phylogeny of the Fungi. Biological Reviews 94, 2101-2137.

Nawawi A, Webster J. 1982 - Sistotrema hamatum sp. nov., the teleomorph of Ingoldiella hamata. Transactions of the British Mycological Society 78, 287-291.

Nguyen TTT, Lee HB. 2016 - Characterization of a Zygomycete fungus, Mortierella minutissima from freshwater of Yeongsan River in Korea. The Korean Journal of Mycology 44, 346-349.

Nguyen TTT, Park SW, Pangging M, Lee HB. 2019 - Molecular and morphological confirmation of three undescribed species of Mortierella from Korea. Mycobiology 47, 31-39.

Nilsson S. 1964 - Freshwater hyphomycetes: taxonomy, morphology and ecology. Symbolae Botanicae Upsalienses 18, 1-130.

Paguigan ND, Raja HA, Day CS, Oberlies NH. 2016 - Acetophenone derivatives from a freshwater fungal isolate of recently described Lindgomyces madisonensis (G416). Phytochemistry 126, $59-65$.

Palmer MA, Covich AP, Finlay BJ, Gibert J et al. 1997 - Biodiversity and ecosystem processes in freshwater sediments. Ambio 26, 571-577.

Park D. 1972 - On the ecology of heterotrophic microorganisms in fresh water. Transactions of the British Mycological Society 58, 291-299.

Pem D, Hongsanan S, Doilom M, Tibpromma S et al. 2019 - https://www.dothideomycetes.org: An online taxonomic resource for the classification, identification, and nomenclature of Dothideomycetes. Asian Journal of Mycology 2, 287-297.

Petersen RH. 1962 - Aquatic hyphomycetes from North America. I Aleuriosporae (Part 1), and key to the genera. Mycologia 54, 117-151

Petersen RH. 1963a - Aquatic hyphomycetes from North America. II Aleuriosporae (Part 2) and B1astosporae. Mycologia 55, 18-29.

Petersen RH. 1963b - Aquatic hyphomycetes from North America. III Phialosporae and miscellaneous species. Mycologia 55, 570-581.

Phookamsak R, Hyde KD, Jeewon R, Jayarama B et al. 2019 - Fungal diversity notes 929-1035: taxonomic and phylogenetic contributions on genera and species of fungi. Fungal Diversity 95, 1-273.

Pinnoi A, Lumyong S, Hyde KD, Jones EBG. 2006 - Fungal colonisation of wood in a freshwater stream at Tad Ta Phu, Khao Yai National Park, Thailand. Fungal Diversity 22, 205-218.

Pinruan U, Hyde, KD, Lumyon S, McKenzie EHC, Jones EBG. 2007 - Occurrence of fungi on tissues of the peat swamp palm Licuala longicalycata. Fungal Diversity 25, 157-173.

Pinruan U, Sakayaroj J, Jones EBG, Hyde KD. 2004 - Aquatic fungi from peat swamp palms: Phruensis brunniespora gen. et sp. nov. and its hyphomycete anamorph. Canadian Journal of Botany 96, 1163-1170.

Porter TM, Martin W, James TY, Longcore JE et al. 2011 - Molecular phylogeny of the Blastocladiomycota (Fungi) based on nuclear ribosomal DNA. Fungal Biology 115, 381-392. 
Powell MJ, Letcher PM. 2014 - Phylogeny and characterization of freshwater Chytridiomycota (Chytridiomycetes and Monoblepharidomycetes). In: Jones EBG, Hyde KD, Pang KL, eds. Freshwater fungi and fungal-like organisms. Berlin: Walter de Gruyter 133-154.

Powell MJ. 2017 - Blastocladiomycota. In: Archibald J, Simpson A, Slamovits C, eds. Handbook of the Protists. Cham: Springer 1497-1521.

Raja HA, El-Elimat T, Oberlies NH, Shearer CA et al. 2015 - Minutisphaerales (Dothideomycetes, Ascomycota): A new order of freshwater ascomycetes including a new family, Minutisphaeraceae, and two new species from North Carolina, USA. Mycologia 107, 845862.

Raja HA, Schmit JP, Shearer CA. 2009 - Latitudinal, habitat and substrate distribution patterns of freshwater ascomycetes in the Florida Peninsula. Biodiversity and Conservation 18, 419-455.

Raja HA, Shearer CA, Tsui CKM. 2018 - Freshwater Fungi. In: eLS Subject Area: Microbiology. Chichester: John Wiley \& Sons Ltd.

Rajashekhar M, Kaveriappa KM. 1996 - Studies on the aquatic hyphomycetes of a sulfur spring in the Western Ghats, India. Microbial Ecology 32, 73-80.

Ranzoni FV. 1953 - The aquatic hyphomycetes of California. Farlowia 4, 353-398.

Ranzoni FV. 1956 - The perfect state of Flagellospora penicillioides. American Journal of Botany 43, 13-17.

Raviraja NS, Sridhar KR, Bärlocher F. 1996 - Breakdown of introduced and native leaves in two Indian streams. Internationale Revue der gesamten Hydrobiologie und Hydrographie 81, 529-539.

Raviraja NS, Sridhar KR, Bärlocher F. 1998 - Fungal species richness in Western Ghat streams, (Southern India); is it related to $\mathrm{pH}$, temperature or altitude? Fungal Diversity 1, 179-191.

Réblová M, Fournier J, Štěpánek V. 2015a - Pisorisporiales, a new order of aquatic and terrestrial fungi for Achroceratosphaeria and Pisorisporium gen. nov. in the Sordariomycetes. Persoonia: Molecular Phylogeny and Evolution of Fungi 34, 40-49.

Réblová M, Fournier J, Štěpánek V. 2016a - Two new lineages of aquatic ascomycetes: Atractospora gen. nov. and Rubellisphaeria gen. et sp. nov., and a sexual morph of Myrmecridium montsegurinum sp. nov. Mycological Progress 15:21.

Réblová M, Réblová K, Štěpánek V. 2015b - Molecular systematics of Barbatosphaeria (Sordariomycetes): Multigene phylogeny and secondary ITS structure. Persoonia: Molecular Phylogeny and Evolution of Fungi 35, 21-38.

Réblová M, Seifert KA, Fournier J, Štepánek V. 2016b - Newly recognised lineages of perithecial ascomycetes: The new orders Conioscyphales and Pleurotheciales. Persoonia: Molecular Phylogeny and Evolution of Fungi 37, 57-81.

Révay A, Gönczöl J. 2011 - Canopy fungi ("terrestrial aquatic hyphomycetes") from twigs of living evergreen and deciduous trees in Hungary. Nova Hedwigia 92, 303-316.

Roa JJH, Virella CR, Cafaro MJ. 2009 - First survey of arthropod gut fungi and associates from Vieques, Puerto Rico. Mycologia 101, 896-903.

Saccardo PA. 1880 - Conspectus generum fungorum Italiae inferiorum. Michelia 2, 1-38.

Samarakoon MC, Hyde KD, Hongsanan S, McKenzie EHC et al. 2019 - Divergence time calibrations for ancient lineages of Ascomycota classification based on a modern review of estimations. Fungal Diversity 96, 285-346.

Sati SC, Arya P. 2010 - Assessment of root endophytic aquatic Hyphomycetes fungi on plant growth. Symbiosis 50, 143-149.

Sati SC, Belwal M. 2005 - Aquatic hyphomycetes as endophytes of riparian plant roots. Mycologia 97, 45-49.

Sati SC, Pant P. 2018 - Evaluation of phosphate solubilization by root endophytic aquatic hyphomycete Tetrcladium setigerum. Symbiosis, 77 141-145.

Sati SC, Pathak R. 2016 - Anamorph (asexual stage) teleomorph (sexual stage) connections in aquatic hyphomycetes. The International Journal of Plant Reproductive Biology 8, 128-135. 
Say R, Denizli A, Yakup Arica M. 2001 - Biosorption of cadmium (II), lead (II) and copper (II) with the filamentous fungus Phanerochaete chrysosporium. Bioresource Technology 76, 6770.

Scherffel A. 1925 - Endophytische Phycomyceten-Parasiten der Bacillariaceen und einige neue Monadinen. Archiv für Protisistenkunde 52, 1-141.

Schulz B, Boyle C. 2005 - The endophytic continuum. Mycological Research 109, 661-686.

Schweikert M, Schnepf E. 1996 - Pseudaphelidium drebesii, gen. et spec. nov. (incerta sedis), a parasite of the marine centric diatom Thalassiosira punctigera. Archiv für Protisistenkunde $147,11-17$.

Seena S, Wynberg N, Bärlocher F. 2008 - Fungal diversity during leaf decomposition in a stream assessed through clone libraries. Fungal Diversity 30, 1-14.

Selosse MA, Vohník M, Chauvet E. 2008 - Out of the rivers: Are some aquatic hyphomycetes plant endophytes? New Phytologist 178, 3-7.

Shearer CA, Bartolata M. 1990 - Experimental determination of in situ competitive interactions among aquatic lignicolous fungi. In: Reisinger A, Bresinsky A, eds. Abstracts 4th International Mycological Congress. Germany: Botanical Institute, University of Regensburg, Regensburg.

Shearer CA, Descals E, Kohlmeyer B, Kohlmeyer J et al. 2007 - Fungal biodiversity in aquatic habitats. Biodiversity and Conservation 16, 49-67.

Shearer CA, Langsam DM, Longcore JE. 2004 - Fungi in freshwater habitats. In: Mueller GM, Bills GF, Foster MS, eds. Measuring and monitoring biological diversity: standard methods for fungi. Washington: Smithsonian Institution Press 513-531.

Shearer CA, Pang KL, Suetrong S, Raja HA. 2014 - Phylogeny of the Dothideomycetes and other classes of freshwater fissitunicate Ascomycota. In: Jones EBG, Hyde KD, Pang KL, eds. Freshwater fungi and fungal-like organisms. Berlin: Walter de Gruyter 25-46.

Shearer CA, Raja HA, Miller AN, Nelson P et al. 2009 - The molecular phylogeny of freshwater Dothideomycetes. Studies in Mycology 64, 145-153-S4.

Shearer CA, Raja HA. 2010 - Freshwater Ascomycetes Database: University of Illinois at UrbanaChampaign, United States. http://fungi.life.illinois.edu/ (Accessed on May 11, 2013, August 10, 2020).

Shearer CA, Webster J. 1985 - Aquatic hyphomycete communities in the River Teign. I. Longitudinal distribution patterns. Transactions British Mycological Society 84, 489-501

Shearer CA, Webster J. 1991 - Aquatic hyphomycete communities in the river Teign. IV. Twig colonization. Mycological Research 95, 413-420.

Shearer CA. 1993 - The freshwater Ascomycetes. Nov Hedwigia 56, 1-33.

Shearer CA. 1995 - Fungal competition. Canadian Journal of Botany 73, 1259-1264.

Simmons DR, Letcher PM, Powell MJ, Longcore JE. 2012 - Alogomyces tanneri gen. et sp. nov., a chytrid in Lobulomycetales from horse manure. Mycologia 104, 157-163.

Singh H. 2006 - Mycoremediation: Fungal bioremediation. John Wiley and Sons Publication, USA.

Singh L, Sati SC. 2020 - Antagonistic activity of isolated root endophytic freshwater fungus Anguillospora longissima against pathogenic fungi. National Academy Science Letters 43, 201-205.

Singh N. 1982 - Cellulose decomposition by some tropical aquatic hyphomycetes. Transactions of the British Mycological Society 79, 560-561.

Sivichai S, Jones EBG, Hywel-Jones N. 2006 - Biodiversity of fungi on the palm Eleiodoxa conferta in Sirindhorn peat swamp forest, Narathiwat, Thailand. Fungal Diversity 10, 113129.

Sivichai S, Jones EBG, Hywel-Jones NL. 2000 - Fungal colonisation of wood in a freshwater stream at Tad Ta Phu, Khao Yai National Park, Thailand. In: Hyde KD, Jones EBG, eds. Fungal Succession. Hongkong: Fungal Diversity Press 113-129. 
Sivichai S, Jones EBG. 2003 - Teleomorphic-anamorphic connections of freshwater fungi. In: Tsui CKM, Hyde KD, eds. Freshwater Mycology. Hong Kong: Fungal Diversity Research Series 10 259-272.

Sivichai S, Jones EBG. 2004 - Stauriella gen. nov., proposed for a new lignicolous basidiomycetous anamorph from freshwater in Thailand. Sydowia 56, 131-136.

Solé M, Müller I, Pecyna MJ, Fetzer I et al. 2012 - Differential regulation by organic compounds and heavy metals of multiple laccase genes in the aquatic hyphomycete Clavariopsis aquatica. Applied and Environmental Microbiology 78, 4732-4739.

Søndergaard M, Laegaard S. 1977 - Vesicular-arbuscular mycorrhiza in some aquatic vascular plants. Nature 268, 232-233.

Sparrow FK. 1960 - Aquatic Phycomycetes (2nd ed. Rev.). University of Michigan Press, Ann Arbor.

Sparrow FK. 1968 - Physoderma Hydrocotylidis and other interesting phycomycetes from California. Journal of the Elisha Mitchell Scientific Society, 84, 62-68.

Sridhar KR. 2009 - Fungi in the tree canopy - An appraisal. In: Rai M, Bridge P, eds. Applied Mycology. UK: CAB International 73-91.

Sridhar KR, Bärlocher F. 1993 - Effect of temperature on growth and survival of five aquatic hyphomycetes. Sydowia 45, 377-387.

Sridhar KR, Bärlocher F. 2000 - Initial colonization, nutrient supply and fungal activity on leaves decaying in streams. Applied and Environmental Microbiology 66, 1114-1119.

Sridhar KR, Chandrashekar KR, Kaveriappa KM. 1992 - Research on the Indian Subcontinent. In: Bärlocher F, ed. The ecology of aquatic hyphomycetes. Berlin: Spinger-Verlag 182-211.

Sridhar KR, Karamchand KS, Hyde KD. 2010 - Wood-inhabiting filamentous fungi in highaltitude streams of the Western Ghats by damp incubation and bubble chamber incubation. Mycoscience 51, 104-115.

Sridhar KR, Karamchand KS, Seena S. 2013 - Fungal assemblage and leaf litter decomposition in coastal streams and riparian tree holes of the south-west India. Mycology 4, 118-124.

Sridhar KR, Sudheep NM. 2011a - Do the tropical freshwater fishes feed on aquatic fungi? Frontiers of Agriculture in China 5, 77-86.

Sridhar KR, Sudheep NM. 2011b - The spatial distribution of fungi on decomposing woody litter in a freshwater stream, Western Ghats, India. Microbial Ecology 61, 635-645.

Srivastava RC, Srivastava GC. 1978 - Fungi associated with the diseases of freshwater fishes. Mycopathologia 63, 121-126.

Steciow MM, Marano AV. 2006 - Blastocladia bonaerensis (Blastocladiales, Chytridiomycetes), a new species from an Argentine channel. Mycotaxon 97, 359-365.

Su HY, Hyde KD, Maharachchikumbura SSN, Ariyawansa HA et al. 2016 - The families Distoseptisporaceae fam. nov., Kirschsteiniotheliaceae, Sporormiaceae and Torulaceae, with new species from freshwater in Yunnan Province, China. Fungal Diversity 80, 375-409.

Suberkropp K, Arsuffi TL, Anderson JP. 1983 - Comparison of degradative ability, enzymatic activity, and palatability of aquatic hyphomycetes grown on leaf litter. Applied and Environmental Microbiology 46, 237-244.

Suberkropp K, Klug MJ. 1980 - The maceration of deciduous leaf litter by aquatic hyphomycetes. Canadian Journal of Botany 58, 1025-1031.

Sudheep NM, Sridhar KR. 2011 - Diversity of lignicolous and Ingoldian fungi on woody litter from the River Kali (Western Ghats, India). Mycology 2, 98-108.

Sudheep NM, Sridhar KR. 2013 - Colonization and diversity of aquatic hyphomycetes in relation to decomposition of submerged leaf litter in River Kali (Western Ghats, India). Mycosphere 4, 456-476.

Sudová R, Rydlová J, Čtvrtlíková M, Havránek P et al. 2011 - The incidence of arbuscular mycorrhiza in two submerged Isoëtes species. Aquatic Botany 94, 183-187. 
Swafford AJM, Oakley TH. 2018 - Multimodal sensorimotor system in unicellular zoospores of a fungus. Journal of Experimental Biology 221, jeb163196.

Swe, A, Jeewon R, Pointing SB, Hyde KD. 2009 - Diversity and abundance of nematode-trapping fungi from decaying litter in terrestrial, freshwater and mangrove habitats. Biodiversity and Conservation 18, 1695-1714.

Tanney J, Miller AN. 2017 - Asexual-sexual morph connection in the type species of Berkleasmium. IMA Fungus 8, 99-105.

Tarda AS, Saparrat MCN, Gómez N. 2019 - Assemblage of dematiaceous and Ingoldian fungi associated with leaf litter of decomposing Typha latifolia L. (Typhaceae) in riverine wetlands of the Pampean plain (Argentina) exposed to different water quality. Journal of Environmental Management 250, 1094092.

Tedersoo L, Liiv I, Kivistik PA, Anslan S et al. 2016 - Genomics and metagenomics technologies to recover ribosomal DNA and single-copy genes from old fruit-body and ectomycorrhiza specimens. MycoKeys 13, 1-20.

Tedersoo L, Sánchez-Ramírez S, Kõljalg U, Bahram M et al. 2018 - High-level classification of the Fungi and a tool for evolutionary ecological analyses. Fungal Diversity 90, 135-159.

Thomas K. 1996 - Freshwater fungi. In: Grgurinovic C, ed.Introductory Volume to the Fungi. Part 2 C. Fungi of Australia Vol IB. Canberra: ABRS 1-37.

Tsui CKM, Baschien C, Goh TK. 2016 - Biology and ecology of freshwater fungi. In: Li DW, ed. Biology of microfungi. Cham: Springer 285-313.

Tsui CKM, Hyde KD. 2003 - Freshwater Mycology. Hongkong: Fungal Diversity Press.

Tsui CKM, Hyde KD, Hodgkiss IJ. 2001a - Longitudinal and temporal distribution of freshwater ascomycetes and dematiaceous hyphomycetes on submerged wood in the Lam Tsuen River, Hong Kong. Journal of the North American Benthological Society 20, 533-549.

Tsui CKM, Hyde KD, Hodgkiss IJ. 2001b - Paraniesslia tuberculata gen. et sp. nov., and new records or species of Clypeosphaeria, Leptosphaeria and Astrosphaeriella in Hong Kong freshwater habitats. Mycologia 93, 1002-1009.

Tubaki K, Watanabe K, Manoch L. 1983 - Aquatic hyphomycetes from Thailand. Transactions of the Mycological Society of Japan 24, 451-457.

Tubaki K. 1957 - Studies on the Japanese Hyphomycetes. III. Aquatic group. Bulletin of the National Science Museum Tokyo 3, 249-268.

Udaiyan K, Hosagoudar VS. 1991 - Some interesting fungi from the industrial water-cooling towers of Madras II. Journal of Economic and Taxonomic Botany 15, 649-66.

Vavra L, Joyon L. 1966 - Étude sur la morphologie, le cycle évolutif, et la position systematique de Callimastix cyclopis Weissenberg 1912. Protistologica 2, 5-16.

Vincent WF. 1988 - Microbial ecosystems of Antarctica. Cambridge University Press, Cambridge.

Vishniac HS. 2006 - Yeast biodiversity in the Antarctic. In: Rosa CA, Péter G, eds. Biodiversity and ecophysiology of yeasts. New York: Springer, 419-440.

Wakefield WS, Powell MJ, Letcher PM, Barr DJS et al. 2010 - A molecular phylogenetic evaluation of the Spizellomycetales. Mycologia 102, 596-604.

Webster J, Descals E. 1981a - Morphology, distribution and ecology of conidial fungi in freshwater habitats. In: Cole GT, Kendrick B, eds. Biology of conidial fungi, vol 1. New York: Academic Press 295-355.

Webster J, Descals E. 1981b - Morphology, distribution, and ecology of conidial fungi in freshwater habitats. In: Kendrick B, ed. Biology of conidial fungi vol. 2. Ottawa: National Museum of Natural Sciences 419-451.

Wellbaum C, Schoenlein-Crusius I, Barros Dos Santos V. 1999 - Filamentous fungi of leaves in the terrestrial and aquatic environment of the island "Ilha dos Eucaliptos", Guarapiranga Reservoir, Sao Paulo State. Revista Brasileira de Botanica 22, 69-74.

Wijayawardene NN, Hyde KD, Al-ani LKT, Tedersoo L et al. 2020 - Outline of Fungi and fungilike taxa. Mycosphere 11: 1-367. 
Wijayawardene NN, Hyde KD, Lumbsch HT, Liu JK et al. 2018a - Outline of Ascomycota: 2017. Fungal Diversity 88, 167-263.

Wijayawardene NN, Hyde KD, Rajeshkumar KC, Hawksworth DL et al. 2017 - Notes for genera: Ascomycota. Fungal Diversity 86, 1-594.

Wijayawardene NN, Pawłowska J, Letcher PM, Kirk PM et al. 2018b - Notes for genera: basal clades of Fungi (including Aphelidiomycota, Basidiobolomycota, Blastocladiomycota, Calcarisporiellomycota, Caulochytriomycota, Chytridiomycota, Entomophthoromycota, Glomeromycota, Kickxellomycota, Monoblepharomycota, Mortierellomyc. Fungal Diversity $92,1-594$.

Wong MKM, Goh TK, Hodgkiss IJ, Hyde KD et al. 1998 - Role of fungi in freshwater ecosystems. Biodiversity \& Conservation 7, 1187-1206.

Wood-Eggenschwiler S, Bärlocher F. 1985 - Geographical distribution of Ingoldian fungi. SIL Proceedings 1922-2010 22, 2780-2785.

Wurzbacher C, Kerr J, Grossart HP. 2012 - Aquatic fungi. In: Grillo O, ed. The dynamics processes of biodiversity - case studies of evolution and spatial distribution. Croatia: Tech Open Learning 227-258.

Wurzbacher C, Rösel S, Rychła A, Grossart HP. 2014 - Importance of saprotrophic freshwater fungi for pollen degradation. PLoS One 9, e94643.

Wurzbacher C, Warthmann N, Bourne EC, Attermeyer K et al. 2016 - High habitat-specificity in fungal communities in oligo-mesotrophic, temperate Lake Stechlin (North-East Germany). MycoKeys 16, 17-44.

Wurzbacher C, Bärlocher F, Grossart HP. 2010 - Fungi in lake ecosystems. Aquatic Microbial Ecology 59, 125-149.

Yang J, Liu JK, Hyde KD, Jones EBG, Liu ZY. 2017 - Two new species in Fuscosporellaceae from freshwater habitats in Thailand. Mycosphere 8,1893-1903.

Yang J, Liu JKJ, Hyde KD, Jones EBG et al. 2019 - Aquimonospora tratensis gen. et sp. nov. (Diaporthomycetidae, Sordariomycetes), a new lineage from a freshwater habitat in Thailand. Phytotaxa 397, 146-158.

Yang J, Liu NG, Liu JK, Hyde KD et al. 2018a - Phylogenetic placement of Cryptophiale, Cryptophialoidea, Nawawia, Neonawawia gen. nov. and Phialosporostilbe. Mycosphere 9, 1132-1150.

Yang J, Maharachchikumbura SSN, Liu JK, Hyde KD et al. 2018b - Pseudostanjehughesia aquitropica gen. et sp. nov. and Sporidesmium sensu lato species from freshwater habitats. Mycological Progress 17, 591-616.

You YH, Park JM, Park JH, Kim JG. 2015 - Diversity of endophytic fungi associated with the roots of four aquatic plants inhabiting two wetlands in Korea. Mycobiology 43, 231-238.

Yuen TK, Hyde KD, Hodgkiss IJ. 1999 - Soft rot decay in tropical freshwater fungi. Material und Organismen 33, 155-161

Zemek J, Marvanová L, Kuniak L, Kadlečíková B. 1985 - Hydrolytic enzymes in aquatic Hyphomycetes. Folia Microbiologica 30, 363-372.

Zhang H, Dong W, Hyde KD, Maharachchikumbura SSN et al. 2017 - Towards a natural classification of Annulatascaceae-like taxa: introducing Atractosporales ord. nov. and six new families. Fungal Diversity 85, 75-110.

Zhang H, Jones GEB, Zhou D, Bahkali AH, Hyde KD. 2011 - Checklist of freshwater fungi in Thailand. Cryptogamie, Mycologie 32, 199-217.

Zhang N, Castlebury LA, Miller AN, Huhndorf SM et al. 2006 - An overview of the systematics of the Sordariomycetes based on a four-gene phylogeny. Mycologia 98, 1076-1087.

Zhang Y, Crous PW, Schoch CL, Hyde KD. 2012 - Pleosporales. Fungal Diversity 53, 1-221.

Zopf W. 1885 - Zur morphologie und Biologie der niederen Pilztiere (Monadinen), Zugleich ein Beitrag zur Phytopathologie. Verlag von Veit \& Comp, Leipzig. 